\title{
Financial and Economic Growth in Europe : Is the Euro Beneficial for All Countries?
}

\author{
Iordanis Kalaitzoglou \\ Audencia Business School, ReMA, France
}

Beatrice Durgheu

Metroline, Department of Finance, London, United Kingdom

\begin{abstract}
We revisit the financial-economic growth nexus, accounting for differential effects of large-scale legislative frameworks, such as political and financial integrations, in Europe. Debt is introduced as an integral component, and potential triple endogeneity is investigated. Empirical findings show that neither political nor financial integration, namely the euro appears to have a direct impact on economic growth. In contrast, only monetary integration has a dual and indirect impact on economic growth. First, the Euro allows for improved access to financing, which enhances economic growth. This increases market values, which further accelerate economic growth. This is only evident within the Eurozone, highlighting a Euro effect, whereas political integration seems to be insufficient in engaging the country in a synergetic endogeneity. Second, improved access to financing induced by the Euro introduces an additional macroeconomic risk of over-borrowing. This reverses the above-mentioned spiral link by decreasing market values and therefore leads the economies to a spiral contraction. Consequently, the suitability of adopting the Euro should depend on each country's ability to balance its dual role, i.e., the improved access to financing and the risk of over-borrowing.
\end{abstract}

\footnotetext{
* Corresponding Author: Iordanis Kalaitzoglou; Audencia Business School, special interest group in Regulation Market structure and Asset prices, 8 Route de la Jonelière-BP 31222, 44312, Nantes Cedex 3, France; Tel: 0033 (240) 37 8102, E-mail: ikalaitzoglou@, audencia.com.

Co-author: Beatrice Durgheu; Metroline, ComfortDelGro House, 329 Edgware Road, Cricklewood, London, NW2 6JP, United Kingdom; Tel: 0044 (208) 2188831, E-mail: bdurgheu@metroline.co.uk.
} 
JEL Classifications: F43, O11, N14

Keywords: Financial Integration, Euro, Economic Growth, Government Borrowing, Generalized Method of Moments

\section{Introduction}

This study investigates the aptness of differential levels of integration in Europe, i.e., political and monetary, by focusing on its impact on the relationship between financial and economic growths, as well as public borrowing levels. Early literature (Schumpeter 1911) recognizes that open market economies seem to be associated with higher economic growth, raising the question of whether and how financial growth is associated with economic growth. Several studies (Diaz-Alejandro 1985, Fry 1978) suggest that a deeper financial system is a pre-condition for economic growth because it reduces transactions costs and accelerates trading, while others (Robinson 1952, 1979, Miller 1998) purport that economic growth requires more intense trading and thus a deeper financial system. Another branch of the literature (Levine 1996, 1997) recognizes that financial and economic growths might interact and potential endogeneity issues might thereby render it difficult to establish direct causal relationships (Collins 2007); thus, they implicitly highlight the relationship's empirical nature.

The underlying theoretical argument that links financial and economic growths is that markets influence the allocation of resources and information cross-sectionally and over time (Merton and Bodie 1995). This is achieved by improving information dissemination (Bagehot 1873, Boyd and Prescott 1986), mobilization of capital and resources (Sirri and Tufano 1995), corporate governance (Myers and Majluf 1984), and reducing risk (Gurley and Shaw 1955, Patrick 1966). A necessary condition for markets to achieve this is some form of integration that allows uninterrupted flows of capital, resources, and information. Kose et al. (2009) argue that liberalization and financial integration appear to have a positive but indirect effect on economic growth, especially for countries with low levels of financial integration and financial deepening, while co-existence of financial integration and liberalization amplify (Alfaro et al. 2004, Durham 2004) their impact.

However, not all studies come to a consensus with regards to the positive impact of financial development on economic growth. According to several economists (Bhagwati 
1998, Stiglitz 2002), increasing capital account liberalization and unfettered capital flows pose a direct instability threat to economies due to the economies' exposure to macroeconomic shocks - a risk that these authors believe outweighs the benefits of liberalization. Relevant literature recognizes three major sources of induced risk. The first refers to over-reliance on market efficiency, which might lead to excessive optimism and thus to the creation of asset bubbles (Gibson et al. 2013). The second refers to market openness (Alessi and Detken 2011, Popov 2011), which might create the conditions for premature growth and thereby overexposure to macroeconomic shocks. Along the same lines, the third source of risk is identified as the funding sources of economic growth, wherein better access to capital markets might lead to excessive borrowing.

Kose et al. (2009) purport that liberalization and financial integration appear to have a positive but indirect effect on economic growth, in spite of the potential induction of instability due to unfettered capital flows; therefore, further integration does not always create growth. A minimum level of financial deepening is required beforehand. This implicitly recognizes that the optimal level and timing of integration depends on the existing relationship between financial and economic growths and that higher integration does not unconditionally accelerate growth. This dynamic is the primary focus of this study, which aims at investigating the impact of various levels of integration by focusing on the financial-economic growth nexus.

This is particularly relevant to Europe, which has promoted financial integration alongside political integration as the defining pillars of the so-called development model (Friedrich et al. 2012). This approach had been mostly unquestioned (Edwards 1998) until the sovereign bond crisis in 2009, when several countries experienced doubledigit slowdowns, which have been attributed to prior excessive optimism (Friedrich et al. 2012), excessive borrowing levels (De Grauwe and Ji 2013), and intense contagion effects and spillovers (Beetsma et al. 2013). Friedrich et al. (2012) highlight the importance of political integration in accelerating growth but fail to address how it affects the financial-economic growth nexus.

This paper investigates the aptness of differential levels of integration in Europe by focusing on how they affect financial and economic growths. First, we differentiate between financial and political integration at an aggregated level and examine their direct and indirect impacts on financial and economic growths. We recognize that financial and economic growths might evolve endogenously and therefore we model explicitly structural endogeneity. Finally, to account for over-capitalization of expectations due to differential levels of integration (Friedrich et al. 2012), we introduce public borrowing 
levels as an integral element of the relationship between financial and economic growths.

Our empirical analysis, conducted on a sample of 27 European countries over a period from 1998 to 2012, highlights a dual effect of the Euro. First, the Euro is found to have a direct positive impact only on financial growth. Markets appear to capitalize stability expectations into enhanced market values, and this has a significant spiral-boosting effect on economic growth, even when debt is high. This link is not fully observed upon considering political integration alone and is absent in non-member states. Second, the Euro allows for increased borrowing, which, under specific circumstances, can enhance economic growth. However, this increased financing has a negative impact on market values and therefore reverses the previous spiral link, suppressing growth. This is more evident during bull market periods. Consequently, the suitability of adopting the Euro depends on the borrowing capacity of each country and its ability to benefit from financial growth in the long term.

\section{Literature Review}

\section{A. Financial and economic growth}

Early literature (Schumpeter 1911) reports a positive correlation between financial and economic growths. Open market economies aim at reducing intermediary costs to assist economic development, whereas centralized economies appear to experience slower growth. ${ }^{1}$ Four major hypotheses have been developed to describe the link between the two variables (Kose et al. 2009). The supply-leading hypothesis (Diaz-Alejandro 1985, Fry 1978, McKinnon 1973, Moore 1986, Shaw 1973) purports that a sustainably deepening financial system can lead to increased economic growth. In contrast, the demand-following hypothesis (Darrat 1999, Demetriades and Hussein 1996, Ireland 1994, Patrick 1966) suggests that increased demand requires more intensive trading and a deeper financial system; financial growth should follow economic growth spikes. More comprehensive approaches (Berthelemy and Varoudakis 1996, Blackburn and Hung

\footnotetext{
Watchel (2003) highlights that the absence of financial growth, especially before 1990, has had significant negative impact on economic growth, especially for economies that experience state intervention.
} 
1998, Demetriades and Hussein 1996, Greenwood and Jovanovic 1990, Greenwood and Smith 1997, Harrison et al. 1999, Saint-Paul 1992) suggest a bidirectional relationship, arguing that economic growth requires financial deepening, which, in turn, further enhances economic growth. Finally, several studies (Lucas 1988, Stern 1989) argue that financial deepening only occasionally has a short-term impact on economic growth. ${ }^{2}$

The theoretical base for discussing the impact of financial growth on economic growth focuses on ameliorating market frictions (Merton and Bodie 1995). An important function of markets in this direction is the dissemination of information and a more efficient allocation of resources. Deeper and more liquid markets should make it easier, compared with individual investors, to collect information (Begehot 1873), either through intermediary institutions (Ramakrishnan and Thakor 1984, Allen 1990, Bhattacharya and Pleiderer 1985) or because firms would have the incentive to do so in order to limit exploitable private information (Grossman and Stiglitz 1980, Kyle 1984, Holmstrom and Tirole 1993). This undeniably could improve resource allocation (Boyd and Prescott 1986). Furthermore, since enhanced capital flows would improve firms' access to capital, the equity capital structure is also expected to change, along with the way information about managerial decisions is disseminated (Berle and Means 1932). Larger shareholders exhibit better means in acquiring this information (Grossman and Hart 1980, 1986, Stulz 1988), and improved corporate governance can better engage with innovation and growth activities. In parallel, improved access to the market can contribute to reducing individual firms' cost of capital by enhancing cross-sectional (Gurley and Shaw 1955, Patrick 1966, Greenwood and Jovanovic 1990, Devereux and Smith 1994) and time (Allen and Gale 1997) diversifications, as well as by reducing liquidity-induced costs (Hicks 1969, Diamond and Dybvig 1983, Levine 1991). Finally, other functions that allow financial deepening to impact economic growth are the improvement of savings' mobilization (Boyd and Smith 1992, Lamoreaux 1994) and facilitation of exchange (Williamson and Wright 1994), which are both costly processes for individuals.

These factors are usually latent, and several empirical proxies exist in the literature to measure one or multiple dimensions of financial deepening, such as the size of financial intermediaries (Goldsmith 1969) and the size of the private institutions with respect to GDP and credit allocation (King and Levine 1993), as well as the level of government ownership in the banking system (La Porta et al. 2002). The use of various proxies

\footnotetext{
2 Recent empirical literature (Manning 2003, Rousseau and Wachtel 2011) confirms that the impact of financial growth on economic development has weakened considerably after 1990 .
} 
yields conflicting results and highlights that the link between financial and economic growths is empirical in nature and that, among other things, the link depends on how individual variables are measured. Furthermore, empirical findings are also affected by the models employed to account for the dynamic nature of the relationship between financial and economic growths. The initial studies (Goldsmith 1969, King and Levine 1993) employ cross-sectional samples, which, despite addressing various dimensions of the relationship, generally ignore causality and temporal dependence (Shan et al. 2001). Therefore, several later studies employ panel data samples and dynamic panel data techniques (Levine 1991, 1997) to extract any endogenous component and focus only on direct impacts. However, reverse causality and potential endogeneity are not explicitly accounted for. Toward this direction, some studies employ Vector Error Correction Models (VECM) to account for the temporal dependence (Ang and McKibbin 2007), but they, too, ignore any structural causality.

\section{B. Financial growth and macroeconomic risk}

However, not all studies consider financial growth to be beneficial. A significant strand of the literature reports a rather negative impact of financial growth on stability. Stiglitz (2000), challenging the idea of business-cycle volatility (Lucas 1987), argues that excessive optimism, enhanced by more advanced financial systems, dramatically increases the probability of asset bubble creation and, consequently, the frequency of macroeconomic shocks (Gibson et al. 2013). More specifically, a deeper financial system can indeed improve resource mobilization, information dissemination, and corporate governance while reducing risk, but all of these rely on the assumption that the markets operate efficiently. In contrast, a deeper interconnected structure that is not efficient could potentially create the unfounded expectations because of the fact that participants expect them to be efficient, which could contribute to an irrational capitalization of expectations (Friedrich et al. 2012). If these countries are connected, contagion effects might become very significant (Beetsma et al. 2013). Unless efficient regulatory practices are in place (Popov and Smets 2011), countries are exposed to a magnified impact on economic growth. Kaminsky and Reinhart (1999) provide empirical evidence of greater exposure to financial crises after a period of high growth, especially for countries that exhibit a parallel growth in their financial systems.

Literature recognizes two sources of risk. First, market openness (Alessi and Detken 
2011, Popov 2011, Popov and Smets 2011) is identified as one of the main causes for the trade-off between the contribution of financial to economic growth and macroeconomic risk. Financial growth is considered a funding and supporting mechanism for economic growth. However, this comes at the price of making the economy more susceptible to immaturely generated growth and external shocks, both resulting from a greater contribution of individual bank risk to systemic risk. In this sense, Kindleberger (1978), Minsky (1986), and Popov and Smets (2011) distinguish between good and bad growth. Second, another source of increased macroeconomic risk is the accumulation of public debt in periods of growth, probably due to irrational optimism (Heinemann et al. 2013). Early literature recognises this negative impact in the form of reduced income or slower investment flows (Buchanan 1958, Meade 1958, Modigliani 1961) or in the form of tighter fiscal and tax policies applied during a post-borrowing period in an effort to improve credibility (Adam and Bevan 2005, Aizenman et al. 2007, Diamond 1965, Saint-Paul 1992). A non-linear relationship between public debt and economic growth has also been reported (Aschauer 2000, Checherita and Rother 2010, Clements et al. 2003, Krugman 1988).

\section{Political and monetary integration}

Heinemann et al. (2013) suggest that political and financial integrations might explain the dual effect of financial growth on economic growth and its non-linearity with debt. They argue that political — and especially monetary - integration can enhance not only the benefits of financial growth (Edwards 1998) but also the contaminating effects of external macroeconomic shocks (Berglof et al. 2009). In addition, external financing is seen as possibly being beneficial to industries that depend on external funding. In contrast, the empirical literature appears to be inconclusive, reporting a rather moderate (Gourinchas and Jeanne 2006, 2007, Kose et al. 2009) or long-term (Kaminsky and Schmukler 2008) positive impact of integration or a slower growth for countries that depend on borrowing rather than on savings (Prasad et al. 2007).

Elaborating on this, Kose et al. (2009) argue that financial integration plays an important role in shaping the relationship between financial and economic growths. The

\footnotetext{
3 These studies argue that public debt increases consumption power and, up to a certain level (e.g., below 40\%, Pattillo et al. 2002), may boost economic growth. However, beyond certain thresholds (e.g., beyond 90\%, Clements et al. 2003, Kumar and Woo 2010), the impact on credibility is disproportional, and thus a negative relationship is observed.
} 
fundamental principle for financial deepening is that it ameliorates resource allocation by limiting market frictions. A necessary condition to achieve this is unrestricted flows of these resources, which require some form of integration. A more liberal market should allow capital to move with fewer restrictions to investments in developing economies, which are expected to yield higher returns. In parallel, a deeper and more mature financial system should also reduce relevant risks involved and therefore attract capital more easily. Consequently, Kose et al. (2009) observe that both financial deepening and financial integration should have a positive effect on economic growth (Frankel and Romer 1999, Dollar and Kraay 2003, Berg and Krueger 2003), but integration should be expected to have a rather indirect impact.

Contrary to this indirect, positive effect, many studies (Rodrik 1998, Bhagwati 1998, Stiglitz 2002) suggest that current account opening and unfettered capital flows expose countries to macroeconomic shocks and external spillover effects. Sudden loss of confidence could result in sudden halts to capital flows, with profoundly negative effects on economic growth. The various currency crises in the 1980s and 1990s have shown that countries with more liberal approaches have been more susceptible to sudden stops (Kaminsky and Reinhart 1999, Edwards 2005), especially when these are combined with low financial deepening and high public levels of debt. Indeed, the accumulation of public debt has been identified as a major source of exposure to external shocks. Eichengreen et al. (2006) argue that the only meaningful form of international capital flows is in the form of debt, which does not share the positive attributes of equity-like flows and therefore might induce inefficient capital allocation (Wei 2006) and increase financial instability (Berg et al. 2004). Introducing capital controls, however, would not reduce risk exposure because it would decrease liquidity in the banking system (Diamond and Rajan 2001) and deprive the country of the necessary conditions for longer-term macroeconomic growth (Jeanne 2003).

Kose et al. (2009) argue that the development of financial integration could, in principle, benefit countries with lower levels of integration, but the cost-benefit analysis for more advanced economies is not straightforward, because it depends on potential endogeneity and threshold effects. They particularly stress that because of the impact of potentially strong endogeneity, financial integration might not be the key to economic growth. This argument is supported by unique country-specific studies, such as those conducted for India and China (Prasad et al. 2003), which report that financial integration is neither a necessary nor sufficient condition for economic growth (Ariyoshi et al. 2000, Bakker and Chapple 2002). Kose et al. (2009) conclude that a more relevant 
question is the suitability of the magnitude and timing of integration, since its impact on economic growth is not unconditional.

Recent studies support this view and provide evidence that financial integration could indeed under some conditions contribute to economic growth. More specifically, financial sector development appears to amplify the benefits of financial integration (Alfaro et al. 2004, Durham 2004), with a minimum level of financial deepening as a prerequisite (Hermes and Lensik 2003). These benefits might include greater diversification and thus might lead to greater macroeconomic stability (Easterly et al. 2001, Denizer et al. 2002, Larrain 2004, Beck et al. 2006), as well as a mitigation of the adverse growth effects of financial crises by shortening both expansion and contraction cycles (Calvo and Talvi 2005, Kose et al. 2004). However, in order for these benefits to be realised, a greater level of integration than financial only (Eichengreen 2001) is required. This empirical evidence highlight the importance of the causality due to potential endogeneity.

This is particularly relevant in the context of European monetary integration and current financial instability. European policies have promoted the open-market approach, pursuing higher levels of political, financial, and trade integration, aspiring to improve government access to borrowing and thus to achieve higher economic growth. Indeed, during the mid-1990s period, externally financed economic growth was realised, but this credit boom is believed to have made the region more vulnerable to external macroeconomic shocks (Berglof et al. 2009). Thereafter, both market openness and excessive borrowing have been criticised in the literature as risk-inducing factors. More specifically, Heinemann et al. (2014) argue that optimism has increased confidence in the sovereign bond market, which decreased borrowing costs, particularly for economies in transition. In contrast, De Grauwe (2011, 2012), De Grauwe and Ji (2013) provide evidence that this confidence has elevated fragility through increased borrowing levels and contagion, to the extent that a sovereign debt crisis was inevitable since governments have no power over money supply. Beirne and Fratzscher (2012) report that increased contagion and herding contagion during the financial crisis has caused a sharp re-focus by financial markets on fundamentals, which eroded the earlier beneficial impact of optimism. In parallel, several studies (Mink and De Haan 2012, Missio and Watzka 2011) show that European Union (EU) countries experience increased contagion effects, especially when tangible bad news hit the market, even if a country's fundamentals do not change dramatically (Gibson et al. 2013). Consequently, these studies recognize that integration intensifies the market reaction in both tails of the distribution, but they do not 
distinguish between the marginal impacts of political versus financial integration.

\section{Methodology}

\section{A. Model}

To analyze the relationship between economic growth and the other two potential endogenous growth determinants - financial growth and government borrowingthe starting point of the empirical approach suggested here is the neo-classical growth model (Mankiw 1992, 1995). Growth of country $i$ in year $t$ is defined as the percentage difference of the logged GDP, i.e., $G_{i t}=\left(\Delta\left[G D P_{i, t}\right] / G D P_{i, t-1}\right)$, which implies that given a convergence parameter, $\lambda>0, G_{i, t}=-\lambda\left(G D P_{i, t}-G D P_{\text {steady state }}\right)$. Assuming that countries are not likely to be at their steady states, transitional dynamics should have a significant impact on growth. The Literature (e.g., Christopoulos and Tsionas, 2004) approximates the long-run steady state of $G D P$ with a linear function of structural parameters, i.e., $f(\cdot)$, which produces a testable equation of the following form:

$$
G_{i, t}=a_{0}+a^{\prime} f\left(X_{\text {Endogenous }}, X_{\text {Exogenous }}\right)+v_{i, t} \rightarrow v_{i, t}=\eta_{i}+\lambda_{t}+\varepsilon_{i, t}
$$

where $a^{\prime}$ is a vector of linear parameters to be estimated, $\eta_{i}$ is an unobservable country effect capturing also the initial GDP state, $\lambda_{t}$ is a time dymmy that captures time unobservable effects, and $\varepsilon_{i, t}$ is a pure idiosyncratic error term. The literature (Arellano and Bond 1991, Arellano and Bover 1995, Blundell and Bond 1998) suggests estimating the linear parameters of Equation (1) using a dynamic panel difference (Arellano and Bond 1991) or system (Arellano and Bover 1995, Alonso-Borego and Arellano 1996, Blundell and Bond 1998) Generalized Method of Moments (GMM) technique. The objective of this approach is to extract the endogenous component of the regressors and, thus investigate their pure impact on economic growth, while the dynamic characteristics of the data are taken into consideration in the moment conditions, imposing that the error term (in the levels and in the first difference) is not autocorrelated and not correlated with the regressors. However, their approach does not address causality among the 
endogenous regressors, which might introduce multicollinearity issues (Mankiw et al. 1995, Leon-Gonzalez and Montolio 2015).

This is a primary objective of the current study, which aims at investigating the differential impact of political and monetary integration by addressing the structural causality among two endogenous regressors, namely financial growth, i.e., $F G=\left(\Delta\left[M C A P_{t}\right] / M C A P_{t-1}\right)$, measured as the percentage change in market capitalization, and debt growth, i.e., $D E B=\left(\Delta\left[\right.\right.$ Debt $\left.\left._{t}\right] / D e b t_{t-1}\right)$, measured by the percentage change in the level of public debt. In line with Christopoulos and Tsionas (2004), the structural causality is modeled by introducing two additional equations that define the long-run equilibrium relations of $F G=\beta_{0}+\beta^{\prime} g\left(X_{\text {Endogenous }}, X_{\text {Exogenous }}\right)+\eta_{F G ; i}+$ $\lambda_{F G ; t}+\varepsilon_{F G ; i, t}$ and $D E B=\gamma_{0}+\gamma^{\prime} z\left(X_{\text {Endogenous }}, X_{\text {Exogenous }}\right)+\eta_{D E B, i}+\lambda_{D E B, t}+\varepsilon_{D E B, i, t}$, explicitly as stochastic endogenous variables, where $g(\cdot)$ and $z(\cdot)$ are linear approximations of the conditional mean of financial and debt growths. Economic growth is explicitly allowed to affect the level of both. This creates a system of testable equations that can be summarized as

$G_{i, t}=\left(a_{0}+\sum_{q} a_{0, q} D_{q, i, t}\right)+\left(a_{1}+\sum_{q=1}^{2} a_{1, q} D_{q, i, t}\right) F G_{i, t}+\left(a_{2}+\sum_{q=1}^{3} a_{2, q} D_{q, i, t}\right) D E B_{i, t}+\sum_{j=3}^{9} a_{j} C V_{j, i, t}+\varepsilon_{1, i, t}$

$F G_{i, t}=\left(\beta_{0}+\sum_{q} \beta_{0, q} D_{q, i, t}\right)+\left(\beta_{1}+\sum_{q=1}^{2} \beta_{1, q} D_{q, i, t}\right) G_{i, t}+\left(\beta_{2}+\sum_{q=1}^{3} \beta_{2, q} D_{q, i, t}\right) D E B_{i, t}+\sum_{j=3}^{9} \beta_{j} C V_{j, i, t}+\varepsilon_{2, i, t}$

$D E B_{i, t}=\left(\gamma_{0}+\sum_{q} \gamma_{0, q} D_{q, i, t}\right)+\left(\gamma_{1}+\sum_{q=1}^{2} \gamma_{1, q} D_{q, i, t}\right) F G_{i, t}+\left(\gamma_{2}+\sum_{q=1}^{2} \gamma_{1, q} D_{q, i, t}\right) G_{i, t}+\sum_{j=3}^{9} \gamma_{j} C V_{j, i, t}+\varepsilon_{3, i, t}$

where $D$ is a vector of dummy variables with $q=(E, E U, H D, T, C)$, which is employed to capture, in a piecewise fashion, potential non-linearities (Henderson et al. 2013). $E$ is a dummy variable that takes the value of 1 when country $i$ uses the Euro as its currency and the value of 0 when the country $i$ uses its own national currency. Equivalently, $E U$ is a dummy variable indicating whether country $i$ has joined the EU (not necessarily adopting the Euro), and $H D$ is a dummy variable identifying countries that have public debt exceeding the $90 \%$ level. $T_{\text {time }}$, time $=(2000, \ldots, 2012)^{\prime}$ is a vector of dummy variables 
that take the value of 1 to indicate a specific year and 0 elsewhere. This accounts for extraordinary macroeconomic effects, such as the beginning of the financial crisis in 2008 2009. Equivalently, $C_{\text {country }}$, country $=(\text { Belgium, ... , UK })^{\prime}$ is a dummy variable that takes the value of 1 to indicate a specific country and 0 elsewhere. This accounts for countryspecific fixed effects. The combination of the two dummy variables captures significant structural breaks in specific countries/time due to regulatory changes, such as the 2003 labour market reforms in Germany. In addition, a conditioning set of exogenous variables, i.e., $\mathrm{CV}$, is uniquely introduced in each equation in the model to account for known determinants of the endogenous variables, thereby reducing heteroskedasticity.

Equation (2.a) investigates the impact of financial growth on economic development. Recent literature provides empirical evidence that the link has dramatically weakened after the 1990s (Rousseau and Wachtel 2011), especially for countries afflicted by financial crises. Under this scenario, coefficient $\alpha_{1}$ would be statistically insignificant. If there is any differential effect resulting from political or monetary integration, then coefficient $\alpha_{2, E U}$ or coefficient $\alpha_{1, E}$, respectively, would have a statistically significant impact on $G D P$. Furthermore, coefficients $a_{2, E U}, a_{2, E}$, and $a_{2, H D}$ investigate the potentially differential effect of excessive borrowing within the EU discussed in earlier literature (Prasad et al. 2007, Reinhart and Rogoff 2010).

Following the relevant literature (King and Levine 1993, Levine 1997), potential endogeneity between financial and economic growths is also examined in Equation (2.b). Coefficient $\beta_{1}$ measures the impact of GDP on financial growth. If both $a_{1}$ and $\beta_{1}$ are statistically significant, a bidirectional relationship may better describe the interaction within Europe. If only one is significant, then either the supply-leading, $a_{1}$, or the demand-following, $\beta_{1}$, hypothesis would be confirmed. Potentially differential effects for the EU or the Euro are captured by $a_{1, E}, a_{1, E U}$, and $\beta_{1, E}, \beta_{1, E U}$.

Furthermore, Equation (2.c) explores how the aforementioned variables affect public borrowing levels. Coefficients $\gamma_{1}$ and $\gamma_{2}$ capture this effect, whereas any differential within the Eurozone would be captured by coefficients $\gamma_{1, E U}$ and $\gamma_{2, E}$. The inclusion of $D E B T$ as an endogenous variable in this system of equations also examines the effect of public borrowing on development. Accelerated $D E B T$, i.e., for direct investments in fiscal policies, could have a direct impact on GDP and at least one of the coefficients $a_{2}$ would be significant. In contrast, insignificant $a_{2} \mathrm{~s}$, with $\beta_{2}$ being significant, would mean that an investment for financial growth that further increases $G D P$ would be a more appropriate strategy. If coefficients $\gamma_{1}$ and $\gamma_{2}$ are found to be significant too, this would indicate that either strategy may be a long-term engaging strategy rather than a short-term approach. 


\section{B. Estimation}

This system of simultaneous equations is estimated with iterative GMM, with lags of dependent variables employed as instrumental variables in order to account for recursive effects. This method is preferred because it requires less strict distributional assumptions yet accounts for heteroskedasticity and autocorrelation of unknown form. Economic and financial growths might follow a lead-lag relationship, but since potential structural endogeneity is primarily investigated, a contemporaneous, simultaneous model is preferred over a VAR/VECM counterpart (Christopoulos and Tsional 2005, Ang and McKibbin 2007). This raises the importance of exploiting the dynamic features of the data in the instruments rather than in the structural forms. We account for dynamic effects by using lags as instruments. This, according to previous literature (Arellano and Bond 1991, Arellano and Bover 1995, Alonso-Borego and Arellano 1996, Blundell and Bond 1998), contributes to estimation in multiple ways: (i) the parameters are estimated under the assumption that they are not correlated with the error terms of subsequent periods; (ii) the structural parameters are estimated taking into consideration the dynamic structure of the data; and (iii) the endogenous component of the conditioning set, i.e., $C V$, which, contrary to $F G$ and $D E B$ that are assumed to be strictly exogenous, is extracted and thus the parameters $\alpha_{j}, \beta_{j}$, and $\gamma_{j}$ capture their pure direct and indirect impacts on growth. The estimation follows the steps below.

$\beta=\left(\alpha_{m, q} \beta_{m, q} \gamma_{m, q}\right)^{\prime}, m=0, \ldots, 10$ and $q=\left(\varnothing, E, E U, H D, T_{\text {time }}, C_{\text {country }}\right)^{\prime}$ are vectors of the parameters to be estimated, $v=(G D P, F G, D E B)$ is a vector of all endogenous variables, and $z_{r}=C V_{r}$ is a vector of all control variables of each equation.

$\mathrm{r}=1,2,3 . e_{1, t}=G D P_{i, t}-E\left[G D P_{i, t} \mid H_{i, t}\right]$ is the error term in Equation (2.a), given the information set $H_{i, t}$ of countries $i$ up to time $t, e_{2, t}=F G_{i, t}-E\left[F G_{i, t} \mid H_{i, t}\right]$ is the error term in Equation (2.b), and $e_{3, t}=D E B_{i, t}-E\left[D E B_{i, t} \mid H_{i, t}\right]$ is the error term in Equation (2.c).

We employ the following moment conditions. To derive consistent and efficient parameter estimates, the idiosyncratic error terms are estimated assuming normality. The forecasting error, $e_{r, t}$, is assumed to have a zero mean $\left(E\left[f_{r, t}^{i}\left(\beta, v_{i, t}\right)\right]=E\left[e_{r, t}\right]=0\right)$. Forecasting errors are assumed to be independent from each other $\left(E\left[f_{r, t}^{k}\left(\beta, v_{i, t}\right)\right]=E\left[e_{x, i, t}\right.\right.$ $\left.e_{y, i, t}\right]=0$, for $\left.(x \neq y) \in r\right)$ and with a homoskedastic, constant variance of $\left(E\left[f_{r, t}^{v a r}(\beta\right.\right.$, $\left.\left.v_{i, t}\right)\right]=E\left[\left(e_{r, t}\right)^{2}\right]=\sigma_{e_{r}}^{2}$. To investigate the dynamic structure of the data (Levine, 2005), the errors should be serially uncorrelated $\left(E\left[f_{r, t}^{l}\left(\beta, v_{i, t}\right)\right]=E\left[e_{r, i, t} e_{r, i, t-j}\right]=0\right.$ and the regressors weakly exogenous. Therefore, previous lags of the exogenous regressors (levels) are assumed to be uncorrelated with $e_{r, t}\left(E\left[f_{r, t}^{z}\left(\beta, v_{r, t}\right)\right]=E\left[e_{r, t} * z_{r, t-j}\right]=0 . \mathrm{s}\right.$ In addition, to avoid 
the inclusion of weak instruments, cross-sectional moment conditions are introduced alongside the endogenous variables $E\left[f_{r, t}^{v}\left(\beta, v_{r, t}\right)\right]=E\left[e_{r, t} \otimes v_{r, t-j} \otimes Q_{r, t-j}\right]=0$, for $j=0,1$, $\ldots, T$, here $j=0,1$. The model is estimated with iterative GMM, and the validity of the moment conditions is tested using the $J$-statistic (Nansen 1982). ${ }^{4}$

\section{Data}

This study employs annual cross-sectional data on financial and macroeconomic indicators for 26 European countries over the period from 1999 to 2012 as summarized in the table below. ${ }^{5}$ All variables are monetary (currency) and seasonally adjusted.

\begin{tabular}{|c|c|}
\hline Variable & Definition \\
\hline MCAP & Market Capitalization (\% of GDP and in $€$ ). \\
\hline GDP & Annual Gross Domestic Product (in $€$ ) \\
\hline INF & Inflation (\%) \\
\hline Interest Rates & 10 -Year Government Bond Yield (\%) \\
\hline Trade & Trade (Imports + Exports in $€$ ) \\
\hline Revenue & General Government Revenue (in $€$ ) \\
\hline Expenditure & General Government Total Expenditure (in $€$ ) \\
\hline Debt & General Government Gross Debt (in $€$ ) \\
\hline Current Account & Current Account Balance (in $€)$ \\
\hline Savings & Gross National Savings (in $€$ ) \\
\hline
\end{tabular}

\footnotetext{
${ }^{4}$ The sample means of $\left(\beta, v_{r, t}\right)=\left[f_{r, t}^{z}\left(\beta, v_{i, t}\right), f_{r, t}^{k}\left(\beta, v_{i, t}\right), f_{r, t}^{l}\left(\beta, v_{i, t}\right), f_{r, t}^{v a r}\left(\beta, v_{i, t}\right), f_{r, t}^{v}\left(\beta, v_{i, t}\right), f_{r, t}^{z}\left(\beta, v_{r, t}\right)\right]^{\prime}$ are defined as $g\left(\beta ; S_{l, Y}\right)=\frac{1}{T} \frac{1}{I}$ $\sum_{i=1}^{I} \sum_{t=1}^{T} f\left(\beta, v_{i, t}\right)$, where $S_{l, T}$ contains the observations of $v_{i, t-j}, j=1, \ldots, T$ of a sample $T$. $\beta$ is chosen so that $g\left(\beta ; S_{I, T}\right)$ closely approximate $f\left(\beta, v_{i, t}\right)$. When the number of moment conditions, $K$, is larger than the number of parameters, $L$, the GMM estimator can be written as $\widehat{\beta}=\operatorname{argmin}\left(g\left(\beta ; S_{I, T}\right) * \widehat{W}_{t} * g\left(\beta ; S_{I, T}\right)\right)$ where $\widehat{W}_{t}$ is a $K \times K$ semi-definite weighting matrix, such as that $\lim _{T \rightarrow \infty} \widehat{W}_{t} \rightarrow W$ (population). $\bar{\beta}$ is estimated with iterative GMM, with a heteroskedasticity consistent covariance matrix (Newey and West 1987) and the validity of model is tested using the $J \equiv\left(g\left(\beta ; S_{T}\right)^{*} * \widehat{W}_{t}^{*} g\left(\beta ; S_{T}\right)\right) \rightarrow X_{K-L}^{2}$ (Hansen 1982). $H_{0}$ is that the model is valid. $J$-statistic is asymptotically Chi-squared with $K-L$ degrees of freedom.

${ }^{5}$ The data is collected from the World Bank's World Development Indicators database and International Monetary Fund sources. The regression data are annual as a percentage of GDP. The 26 countries employed are (in alphabetical order): Austria, Belgium, Bulgaria, Cyprus, the Czech Republic, Denmark, Finland, France, Germany, Greece, Hungary, Ireland, Italy, Latvia, Lithuania, Luxemburg, Malta, the Netherlands, Norway, Poland, Portugal, Slovakia, Slovenia, Spain, Sweden, and the UK. Regional criteria have been applied alongside data availability.
} 
The primary concern refers to the proxy of financial growth. Levine (2005) argues that physical capital accumulation does not contribute much to economic growth (Jorgenson 1995, 2005) and therefore a study of the link between financial and economic growths should focus on a measure of development rather than on aggregated savings. Kose et al. (2009) also maintain that because the macroeconomic impact of financial integration cannot be captured by conventional measures of integration and financial deepening, a market-based measure is needed. Furthermore, Friedrich et al. (2012) suggest that excessive optimism sets the base for irrationally capitalized expectations of stability and thus leads to excessive levels of borrowing at a cost that does not fully reflect fundamentals. We introduce public borrowing levels in our analysis as an integral part of the financial-economic growth nexus and postulate that any measure failing to capture market expectations could not reveal the potentially endogenous inter-relations between debt and the other two variables. Following Beck et al. (2000, 2008), the percentage change of MCAP, is employed as a proxy for financial growth. This measure has been chosen on the grounds that it accounts not only for the quality and depth of the financial sector but also for two other things. First, it is a collective measure of intracountry economic entities. Recent studies (Abiad et al. 2009, Heinemann et al. 2013, Imbs 2006, 2007) emphasize the importance of micro-level data. However, because our study focuses on governmental policies rather than on firm level analysis, the macrolevel approach is more appropriate. Market capitalization measures - albeit rigidlyfinancial growth as the sum of all individual entities within an economy and therefore is a measure of financial activity that does not ignore firm-specific effects. Second, the percentage change of MCAP accounts for investor opinions concerning risk, both unsystematic (each individual firm) and systematic (economy as a whole).

The other fundamental variables in our modelling include economic growth and debt. With respect to economic growth, following Levine (1997), we use the percentage growth of GDP. We consider public borrowing levels because in Europe, they have been the major burden in the peripheral economies that amplified the impact of restrained capital flows. The level of debt in the sample period has been steadily increasing and this variable is accordingly not stationary. Therefore, we employ the first percentage difference. We purport that this also accounts for the dynamic character of the panel dataset we have employed and that it should be expected to be more correlated with changing expectations and thus with our measure of financial growth. In Europe, financial and political integrations have been very significant contributors to economic growth, and the foundation of this relationship rests upon capitalization of expectations. 
Optimism has been reflected in market valuations and thus in capital flows. This, in turn, has allowed a better mobilization of resources and consequently growth. However, this growth was externally financed and at some point, public borrowing was restricting rather than financing growth. We postulate that the impact of expectations should be better reflected in the rates at which that financial and economic growths accelerated with respect to the growth rate of borrowing.

Another important element in our study is the distinction between differential degrees of integration. Kose et al. (2009) make an explicit distinction between de jure measures - i.e., explicit measures such as capital controls - and de facto measures - i.e., implicit measures that reflect legal restrictions - of financial integration, suggesting that a combination of the two should better reflect the openness of an economy. ${ }^{6}$ To account for de jure measures, we employ a combination of dummy variables that account for country-specific and larger-scale legislation effects. The country-specific effects, $C$, implicitly capture the intensity of explicit measures among other unobservable effects. In addition, the dummy variables $E U$ and $E$ capture the effects of two different levels of explicit legislation. The former captures the political integration within the EU and the latter captures financial integration within the monetary union, namely the Euro. Both are measures of differential degrees of integration that are explicitly regulated on an integrated level. $E U$ and $E$ are expected to affect market expectations and therefore financial and depth growth, thereby indirectly impacting economic growth. However, in practice, their impact on the market openness of individual countries, which is captured by the combination of $C, E U$, and $E$, might not be reflected in the de facto measures of financial integration. Therefore, we use the variable $\operatorname{Tr} d_{t}=\Delta\left(\right.$ Trade $\left._{t}\right)$, which captures changes in trade openness, measured as the sum of the monetary value of imports and exports. Trade openness is a conventional measure of de facto financial integration (Kose et al. 2009).

Furthermore, other variables are also introduced in the model to account for known $G D P$ determinants, thereby reducing heteroskedasticity. $C V=(E X P, R E V, S A V, I N F$, $I R, \operatorname{Trd}, C A B)^{7}{ }^{7}$ Following the early literature (Arrow and Kurz 1970, Diamond 1989),

\footnotetext{
${ }^{6}$ Kose et al. (2009) argue that in practice, there are explicit measures that limit capital flows, which are necessarily strictly imposed. On the contrary, other countries that might follow liberal practices might experience low capital flows. Consequently, in order to better capture nominal integration - i.e., de jure - and effective integration-i.e., de facto - a combination of the two is needed.

${ }^{7}$ The suggested model does not try by any means to investigate the determinants of economic or financial growth, or public debt. The focus lies on potential endogeneity, accounting for some control variables. Please note that in Equation (2.a), CAB is employed instead of Trade openness because the balance of imports/exports is expected to determine long-term growth. In contrast, in Equation (2.b), Trade openness is preferred because it is a better indicator of total trading activity. In Equation (2.c), inflation is excluded because it is expected to have a simultaneously increasing (higher monetary value) and decreasing (lower value of existing liabilities) impact on debt levels, and thus
} 
$E X P=\Delta \log \left(\right.$ Expenditure $\left._{t}\right)$ is used to capture changes in fiscal policies, particularly the impact of government spending on economic growth. Similarly, $R E V=\Delta \log \left(\right.$ Revenue $\left._{t}\right)$ captures the other side of fiscal policies, such as changes in general government revenue. $C A B=$ Current Account / GDP measures the current account balance as a proportion of $G D P$. Finally, to account for the convergence of interest rates within the Eurozone, the 10-year government bond yields are employed, with $I R=\Delta$ (Interest Rates $\left._{t}\right)$ measuring the change in prevailing yields and reflect changes in the fundamentals. This is closely linked to our measure of financial growth, which also captures investors' expectations.

\section{Empirical Findings}

\section{A. Non-parametric analysis}

\section{Initial observations}

The average economic growth in Figure 1 is positive at 5.29\%, and overdispersed (std. is $6.48 \%$ ), which is somewhat expected because of the inclusion of both developing and developed economies, as well as a structural break in October 2008. The negative skewness $(-0.0442)$ and high kurtosis (5.6059) show that high dispersion is mainly due to the post-2008 contraction experienced by many countries. Furthermore, market capitalization accounts for around $65 \%$ of $G D P$, which shows that the financial sector plays a significant role in these economies. It is also highly dispersed, with a significantly long right tail (kurtosis is 11.5734 and skewness is 2.0959). In several cases, the market value of listed companies exceeds $G D P$ by a maximum factor of 4.62 , which indicates significant exuberance, mainly prior to 2008 (Shiller 2005). The contribution of political and financial integrations to this confidence and its link with economic growth are the main areas of focus in this study.

$D E B T$ accounts for approximately $61 \%$ of GDP. Its longer right tail (skewness is 3.6013 and kurtosis is 20.8301) shows that several countries sustain considerably higher debt levels, in some cases exceeding 100\%. This should be more pronounced after 2008, when $G D P$ declined without a proportional decrease in public debt. A negative median, 
$-€ 0.728 \mathrm{~b}$, for $C A B$, shows that imports exceed exports in most cases. Consistently with Trade, $C A B$ is significantly overdispersed with some extreme observations at both ends of the distributions. This highlights the inhomogeneity of the structure of the countries that constitute the union. The literature recognizes the combination of negative $C A B$ and high debt as a major determinant of increased exposure to macroeconomic shocks, especially under reduced flexibility induced by monetary integration.

\section{Figure 1. Distribution and descriptive statistics}
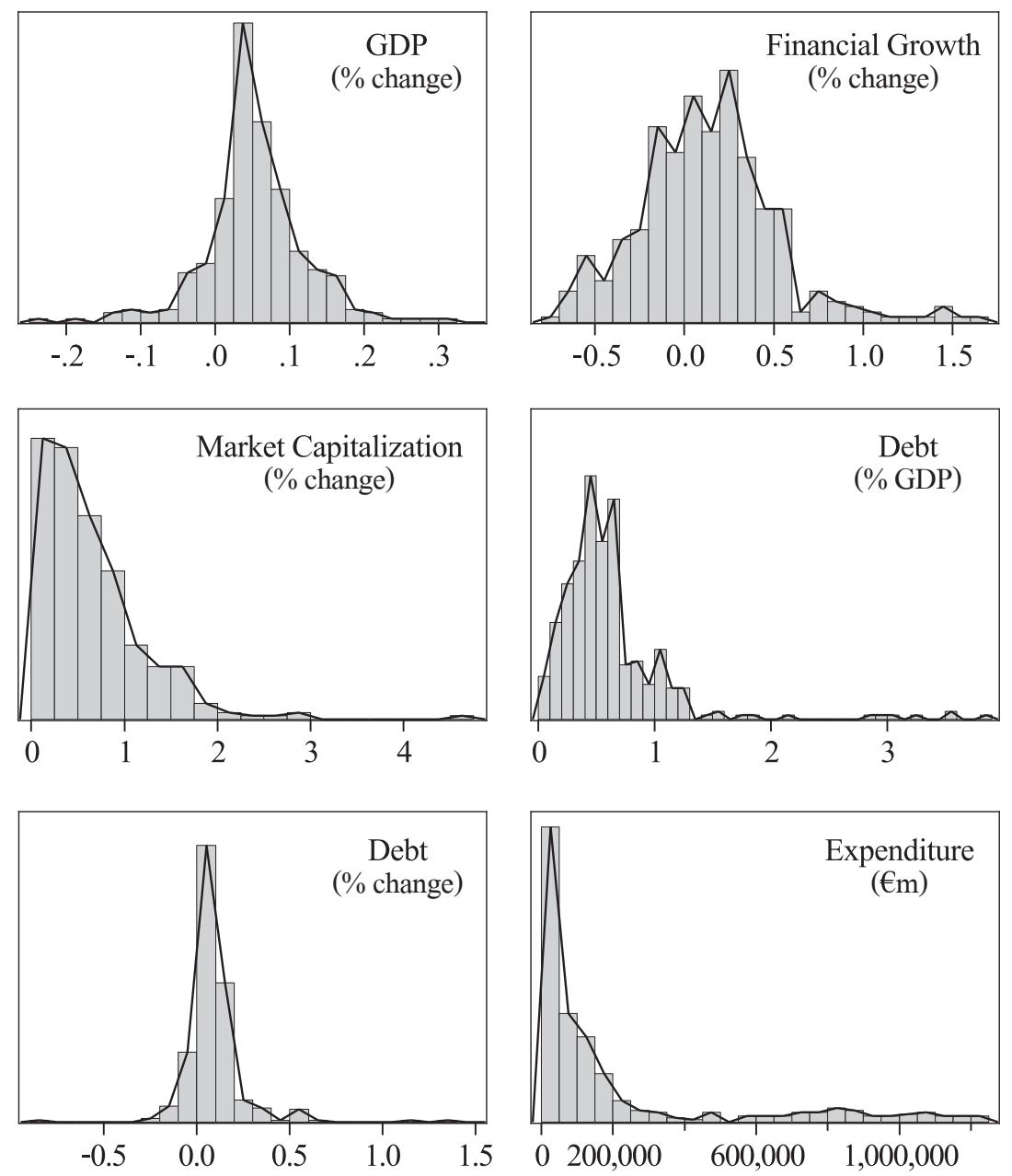

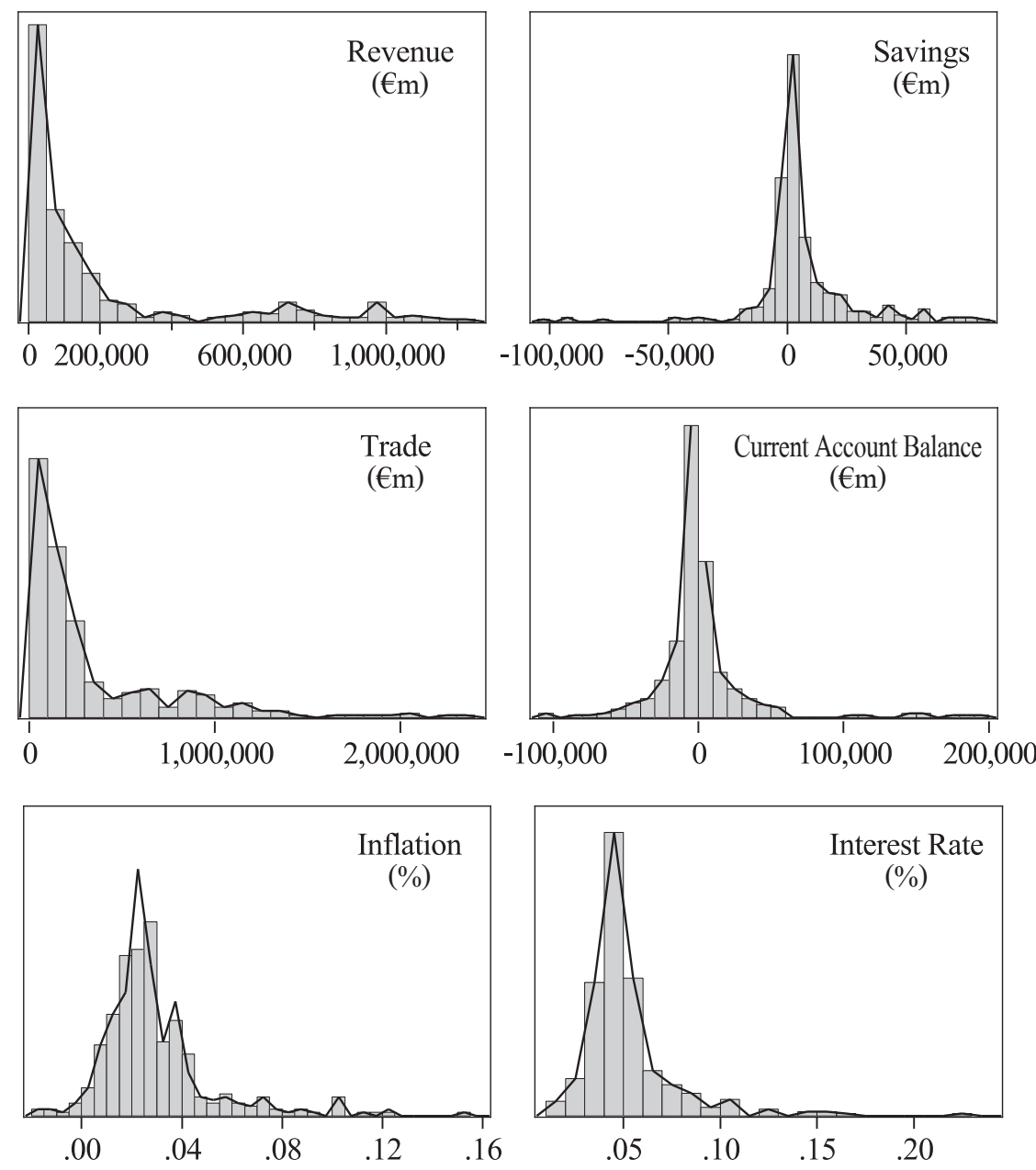


\begin{tabular}{|c|c|c|c|c|c|c|c|c|c|c|}
\hline 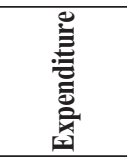 & 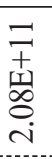 & 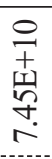 & $\begin{array}{l}\text { I } \\
+ \\
\text { I } \\
\text { ป } \\
-\end{array}$ & $\begin{array}{l}8 \\
\text { o } \\
\text { 亲 } \\
0 \\
0 \\
\end{array}$ & 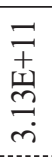 & 官 & $\begin{array}{l}\text { के } \\
\text { oे } \\
\text { in }\end{array}$ & 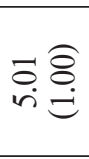 & 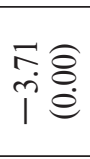 & \multirow{13}{*}{ 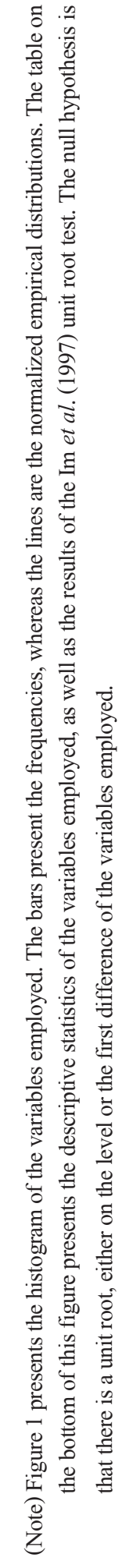 } \\
\hline 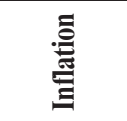 & 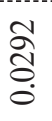 & 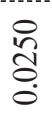 & $\frac{0}{n}$ & $\begin{array}{l}\frac{0}{2} \\
0 \\
0 \\
1\end{array}$ & $\begin{array}{l}\frac{\infty}{\pi} \\
\stackrel{0}{0}\end{array}$ & ڤิ & $\begin{array}{l}\infty \\
\infty \\
\infty \\
\infty \\
\infty\end{array}$ & 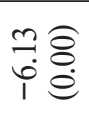 & & \\
\hline 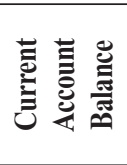 & 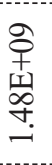 & \begin{tabular}{l}
$\infty$ \\
0 \\
+ \\
1 \\
$\infty$ \\
\multirow{1}{1}{} \\
1
\end{tabular} & $\begin{array}{l}\overline{7} \\
+ \\
\text { 妾 } \\
\text { a }\end{array}$ & 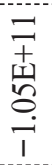 & 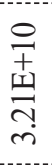 & $\frac{n}{n}$ & $\begin{array}{l}\infty \\
\stackrel{\infty}{0} \\
\underset{0}{0} \\
\underline{0}\end{array}$ & 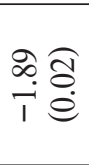 & & \\
\hline 䔍 & 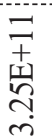 & 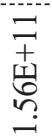 & 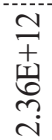 & 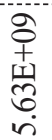 & 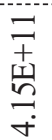 & $\frac{\stackrel{?}{f}}{\stackrel{\sim}{\sim}}$ & $\begin{array}{l}\infty \\
\infty \\
\infty \\
\infty\end{array}$ & 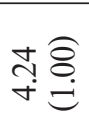 & 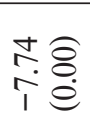 & \\
\hline . & $\begin{array}{l}\text { gे } \\
+ \\
\text { I্ } \\
\text { g. } \\
\text { in }\end{array}$ & 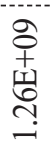 & $\begin{array}{l}0 \\
+ \\
+ \\
\text { 19 } \\
8 \\
\infty\end{array}$ & 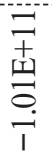 & $\begin{array}{l}\stackrel{0}{1} \\
+ \\
\text { 四 } \\
0 \\
\text { i }\end{array}$ & $\frac{a}{\beth}$ & \begin{tabular}{l}
2 \\
\multirow{0}{0}{} \\
$\stackrel{0}{0}$ \\
0
\end{tabular} & 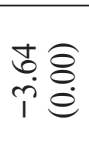 & & \\
\hline 产 & 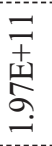 & 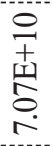 & $\begin{array}{l}\text { I } \\
+ \\
\text { I } \\
\text { ป }\end{array}$ & 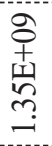 & 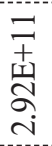 & 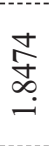 & 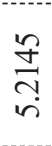 & $\begin{array}{l}\text { rூ } \\
\text { rid }\end{array}$ & 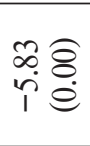 & \\
\hline 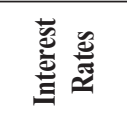 & $\frac{\pi}{\mathscr{2}}$ & \begin{tabular}{l}
$\overrightarrow{0}$ \\
\multirow{0}{0}{} \\
$\stackrel{0}{0}$
\end{tabular} & 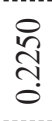 & 导 & तิ & $\begin{array}{l}\overrightarrow{\mathrm{d}} \\
\infty \\
\text { i }\end{array}$ & $\begin{array}{l}\text { 守 } \\
\infty \\
i\end{array}$ & กิ & 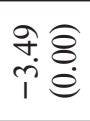 & \\
\hline 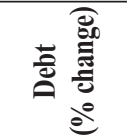 & \begin{tabular}{l}
4 \\
\multirow{2}{0}{} \\
0 \\
0 \\
0
\end{tabular} & $\frac{\infty}{8}$ & 辛 & $\begin{array}{l}0 \\
\infty \\
\infty \\
\infty \\
0 \\
1\end{array}$ & $\frac{n}{n}$ & 衣 & 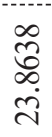 & 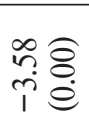 & & \\
\hline 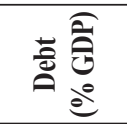 & 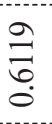 & $\frac{\substack{+n}}{a}$ & $\begin{array}{l}\infty \\
\stackrel{\infty}{\infty} \\
\infty \\
\dot{\infty}\end{array}$ & $\begin{array}{l}\text { ְై } \\
\stackrel{0}{0}\end{array}$ & $\begin{array}{l}\text { oे } \\
\text { +ా } \\
\text { +. }\end{array}$ & $\begin{array}{l}\frac{m}{8} \\
\stackrel{8}{0}\end{array}$ & 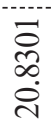 & ¿ & बृत् & \\
\hline 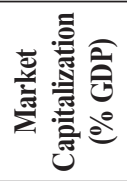 & 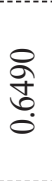 & \begin{tabular}{l}
$n$ \\
\multirow{n}{n}{} \\
$n$ \\
0
\end{tabular} & $\begin{array}{l}8 \\
\text { ర్ర } \\
+ \\
+\end{array}$ & $\frac{n}{\infty}$ & $\stackrel{n}{n}$ & $\begin{array}{l}\hat{2} \\
\text { ò } \\
\text { i }\end{array}$ & $\begin{array}{l}\text { 志 } \\
\text { ñ } \\
=\end{array}$ & 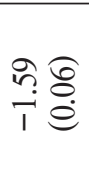 & & \\
\hline 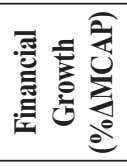 & 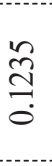 & $\begin{array}{l}\infty \\
\stackrel{\infty}{0} \\
0\end{array}$ & 尔 & 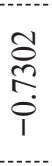 & 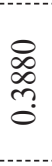 & $\begin{array}{l}n \\
\tilde{n} \\
\stackrel{0}{0} \\
0\end{array}$ & $\frac{8}{2}$ & 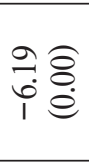 & & \\
\hline 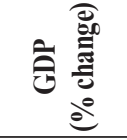 & $\begin{array}{l}\text { ते } \\
\text { ठै. } \\
\text {. }\end{array}$ & 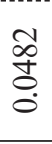 & $\frac{\tilde{n}}{\mathfrak{n}}$ & 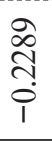 & \begin{tabular}{l}
$\infty$ \\
\multirow{0}{0}{} \\
$\stackrel{0}{0}$
\end{tabular} & $\begin{array}{l}\text { Ỹ } \\
\stackrel{J}{0} \\
\stackrel{0}{1}\end{array}$ & $\begin{array}{l}\text { हे } \\
\text { है } \\
\text { in }\end{array}$ & 효 & & \\
\hline & $\stackrel{\Xi}{\Xi}$ & : & है & 离 & 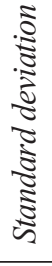 & 永 & $\stackrel{2}{\stackrel{2}{\Sigma}}$ & 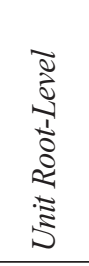 & 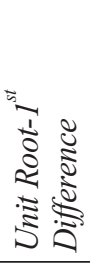 & \\
\hline
\end{tabular}




\section{Financial growth and economic growth}

Figure 2 presents graphically the link between economic growth, financial growth (Panel A C), and MCAP (Panel D F). Panel A shows that financial and economic growths tend to be positively correlated with countries exhibiting simultaneous financial and economic growths. According to Panel B, this seems to be more intense in the countries that have joined the Euro, since the dots seem to be more aligned to a positive correlation, unlike the pattern seen for countries that have kept their national currencies, which exhibit more observations closer to the $\mathrm{XX}^{\prime}$ axis. Panel $\mathrm{D}$ shows an overall declining link between $M C A P$ and economic growth. However, there are several large observations close to the YY' axis, showing that some countries have achieved high market value without necessarily experiencing high economic growth (or showing that small increases in economic activity can spark high market values). The distinction becomes clearer in Panel E and Panel F. In the Eurozone, the strength of the link between market values and economic growth seems to be exponentially increasing. In contrast, in countries that have kept their national currencies, two subgroups are observed. In the first group, higher economic growth is not associated with high market values, whereas in the second, some very high figures are observed for $M C A P$ in countries with low economic growth. The overall link tends to be rather negative but with no clear trend.

Figure 2. Economic growth and market capitalization

A

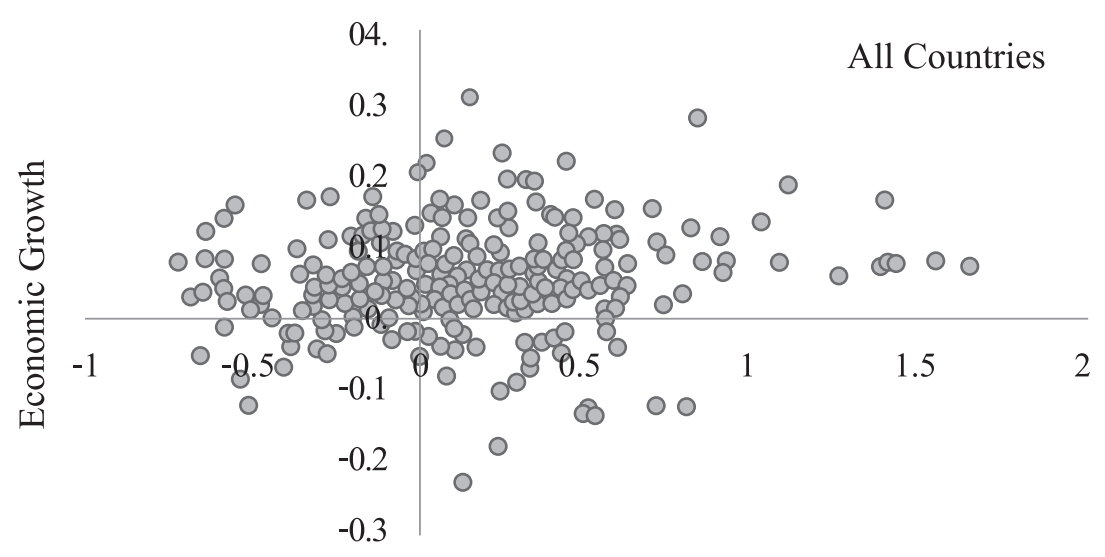

Financial Growth 
B

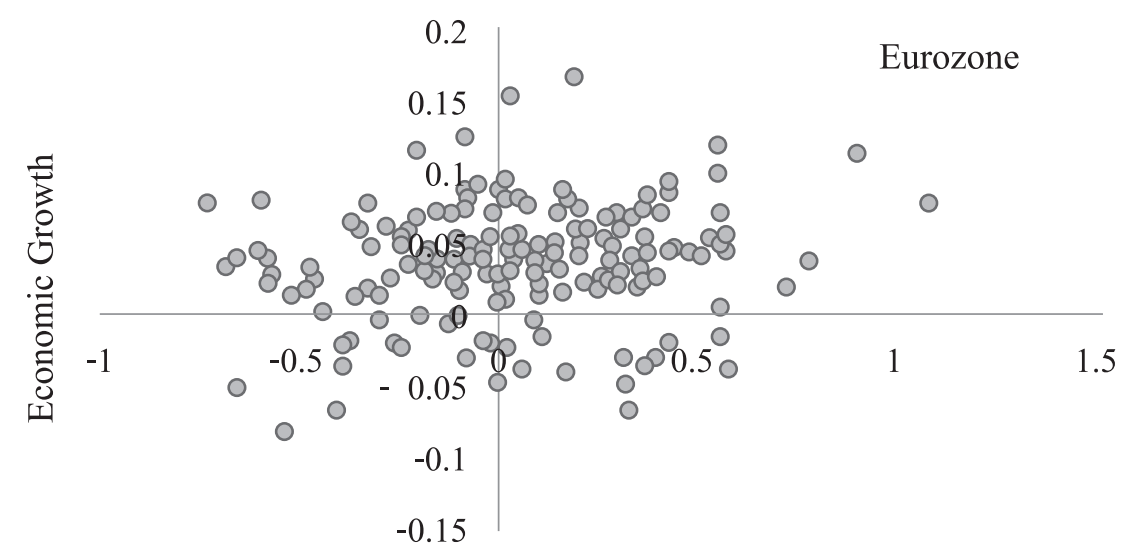

Financial Growth

C

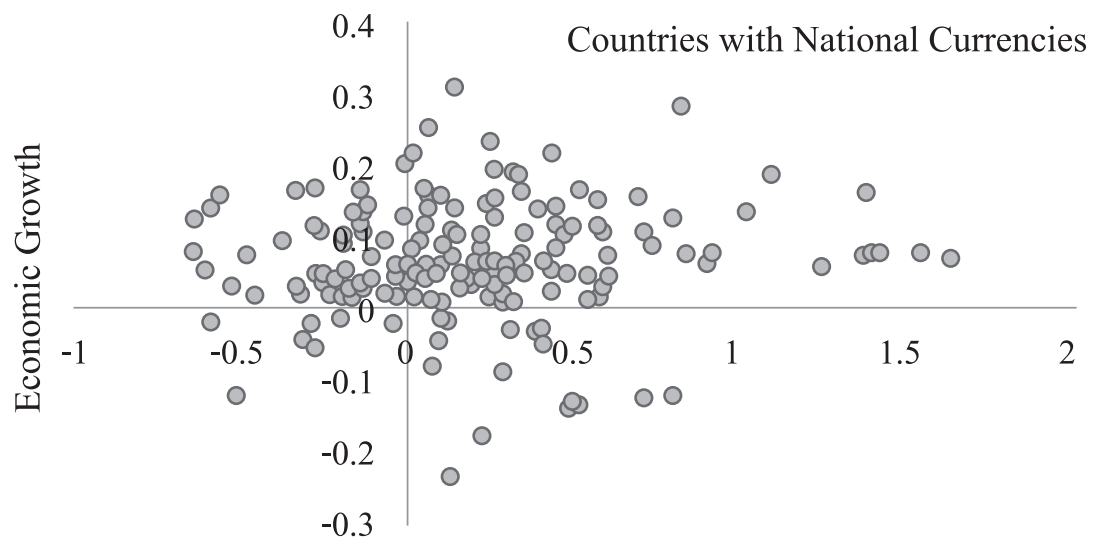

Financial Growth 
D

(\% of GDP)

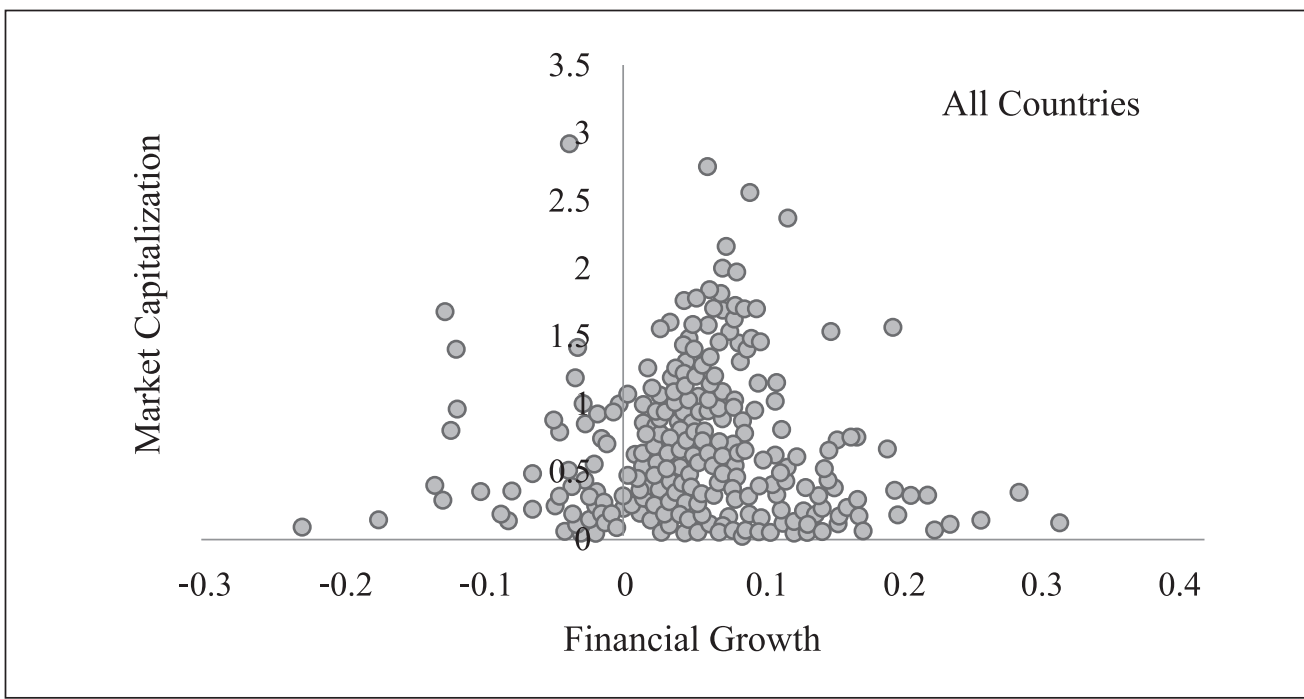

E

(\% of GDP)

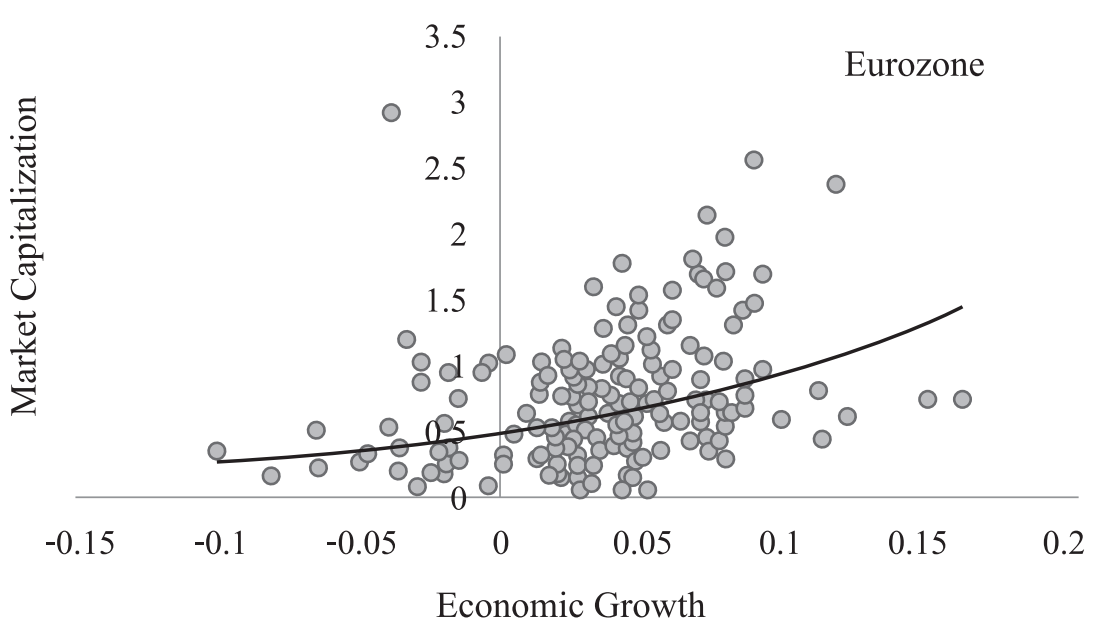




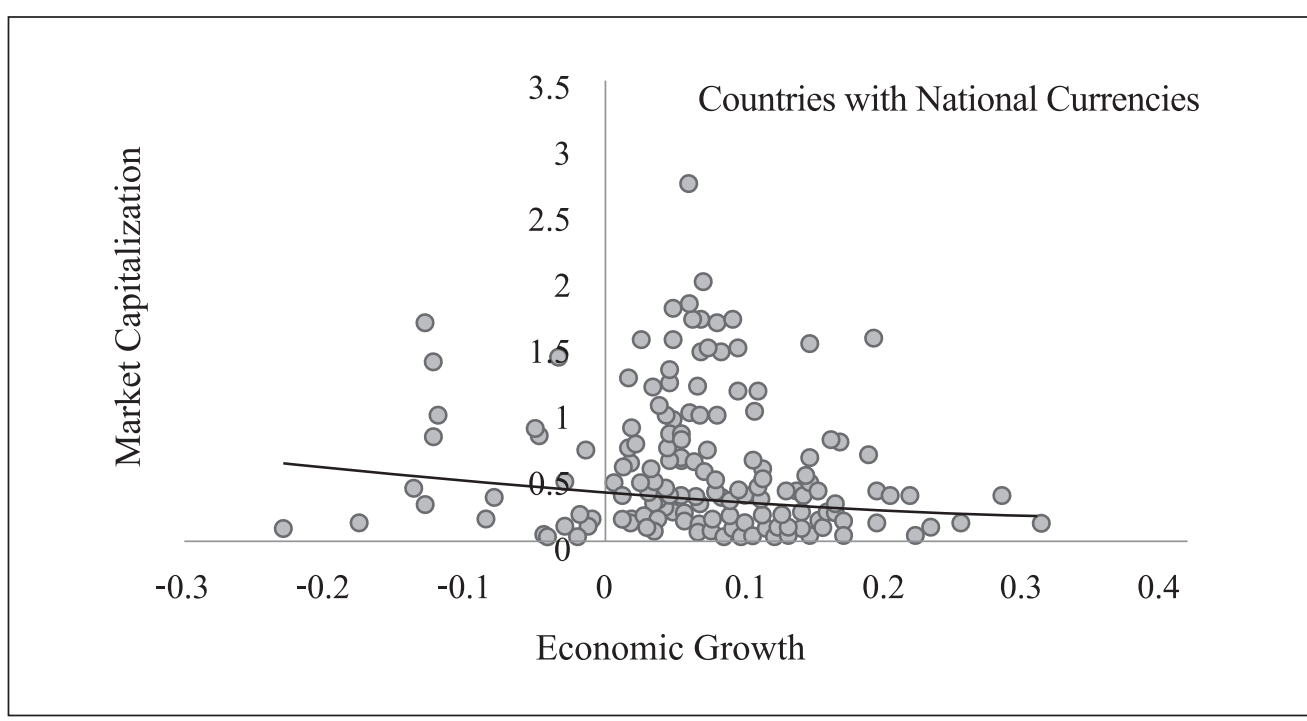

(Note) Figure 2 presents economic growth, defined as \% change of GDP, over market capitalization, defined as MCAP as \% of GDP, and financial growth, defined as \% change of MCAP, across all countries, as well as across countries that have adopted the Euro and those that have retained their national currency. The last column presents the Granger causality test for GDP and MCAP.

Figure 3 presents the relationship among economic growth, financial growth, and debt. In the figure, economic and financial growths both appear to indeed be linked, and this link seems to strengthen over time, particularly after 2008. In the period prior to 2008, Panel B and Panel C reveal that the link is relatively weaker in non-Eurozone countries. However, after 2008, the volatility of both financial and economic growths is higher for this sub-sample, indicating that the Euro might cushion the impact of a macroeconomic shock on participating countries. Several studies (Manning 2003, Rousseau and Wachtel 2011) report that the link between economic and financial growths has weakened significantly, especially after 1990. However, in the period following 2008, their link appears to strengthen again, following a lead-lag pattern. This shows that this link might either be cyclical, i.e., depending on macroeconomic cycles, or that it is a natural consequence of a macroeconomic shock. ${ }^{8}$

\footnotetext{
${ }^{8}$ In this study, we investigate the latter, without necessarily ignoring the first. We focus on the link between financial and economic growth and the impact of monetary integration. As a measure of financial growth, MCAP reflects market expectations and thus is expected to better capture potential Euro effects. If there are cyclical patterns, they should be reflected in market prices, assuming rationality. Relaxing the assumption of rationality or investigating the link between business cycles and macroeconomic shocks would deviate from the current focus, which is potential Euro effects.
} 
Figure 3. Financial growth, economic growth, and debt

\section{A. Total}

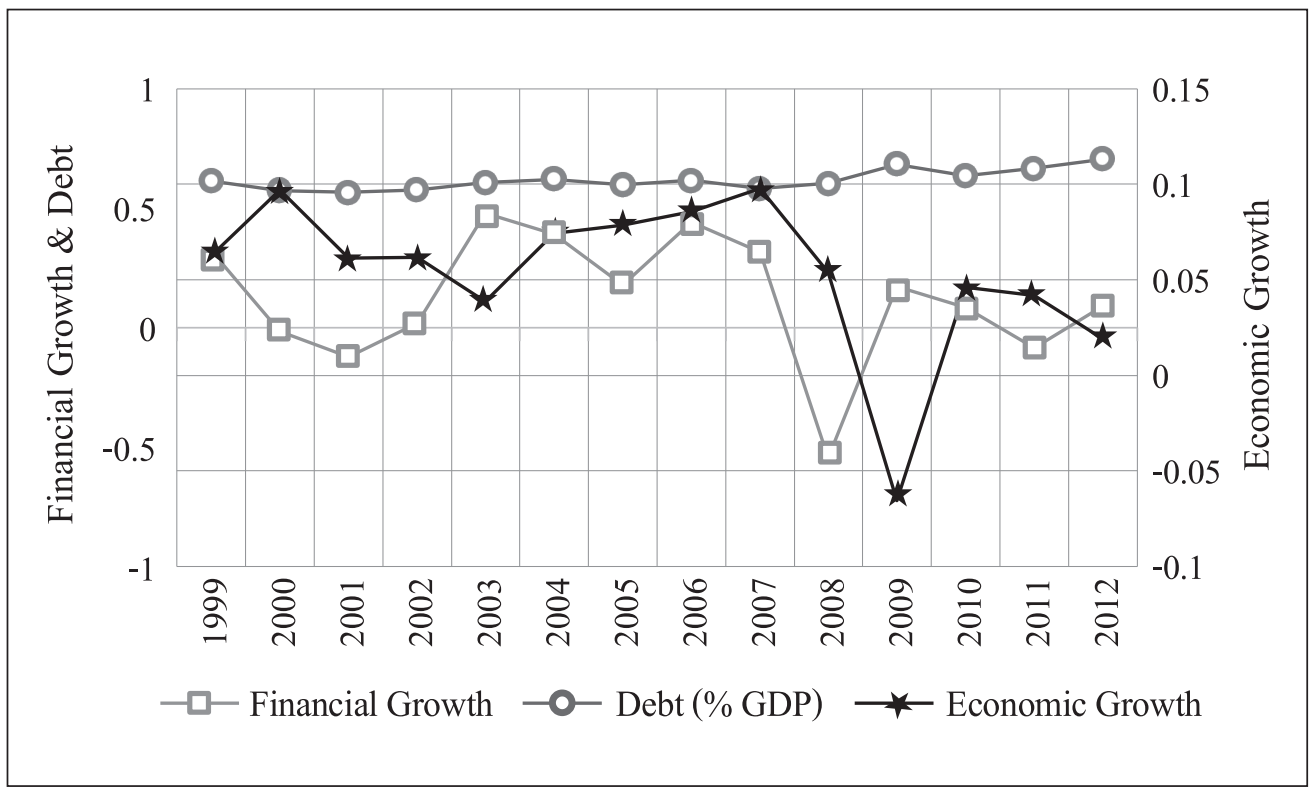

B. Eurozone

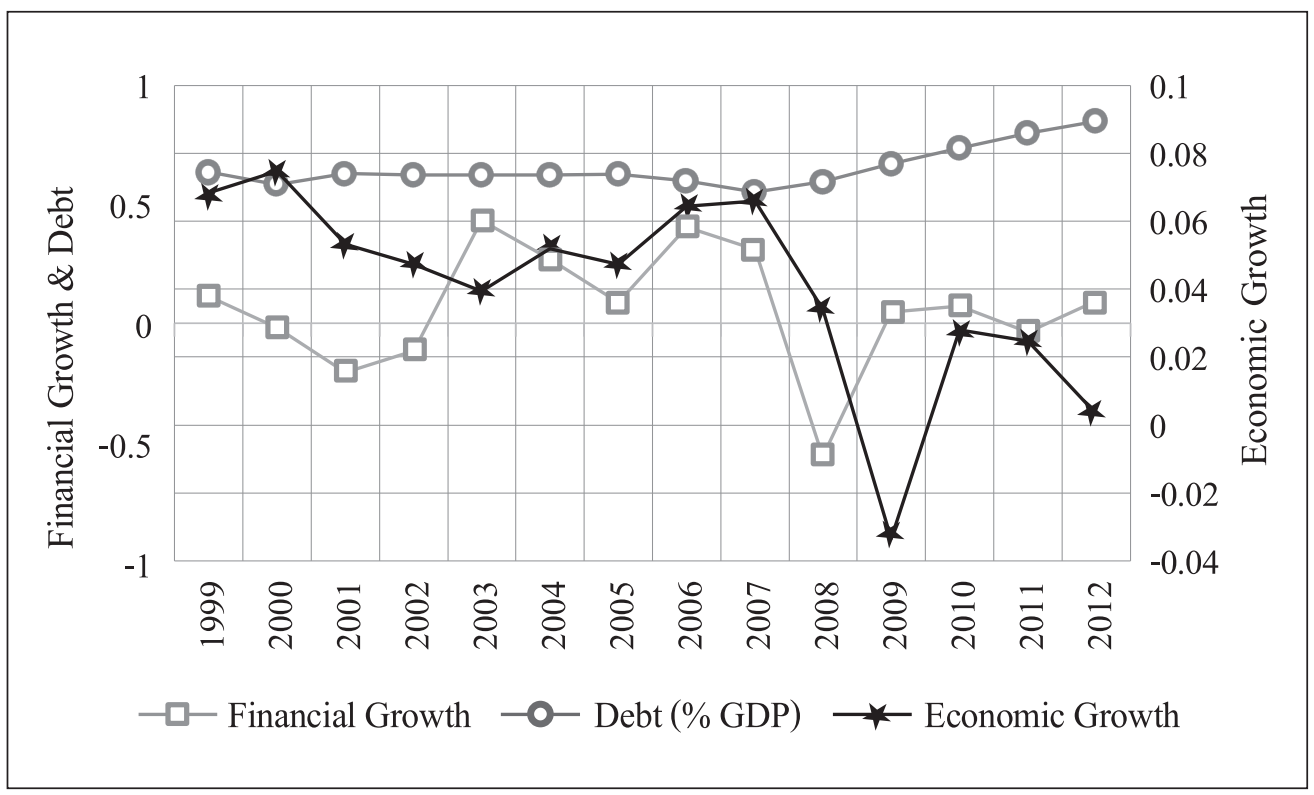




\section{Eurozone}

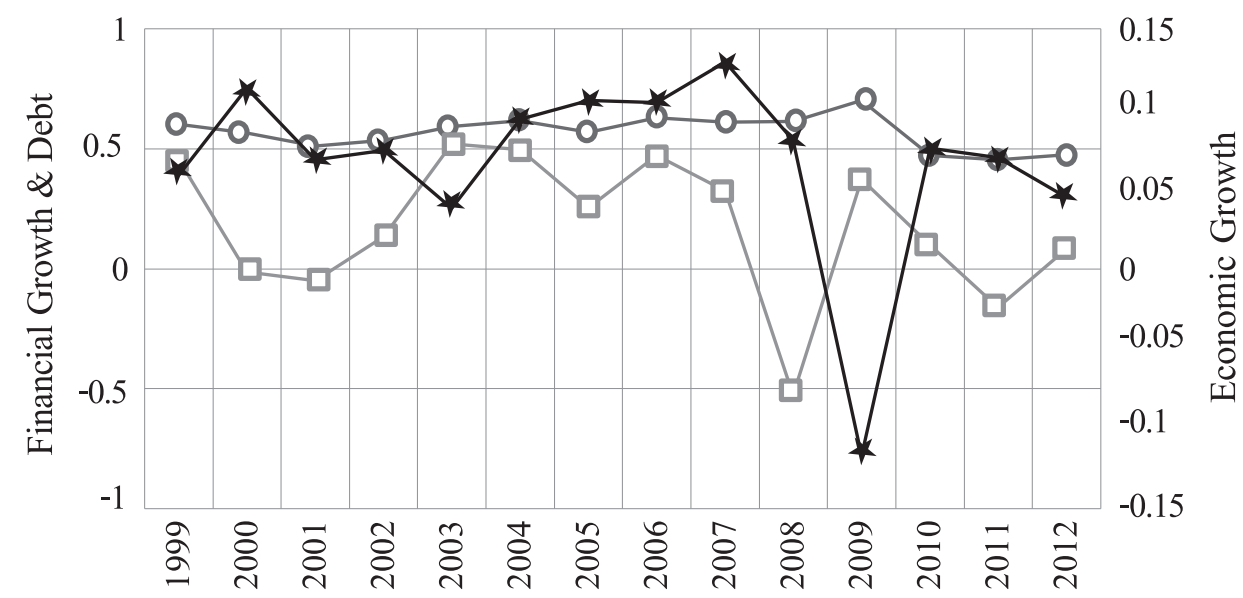

- - Financial Growth - - Debt (\% GDP) - Economic Growth

D. Debt $<90 \%$

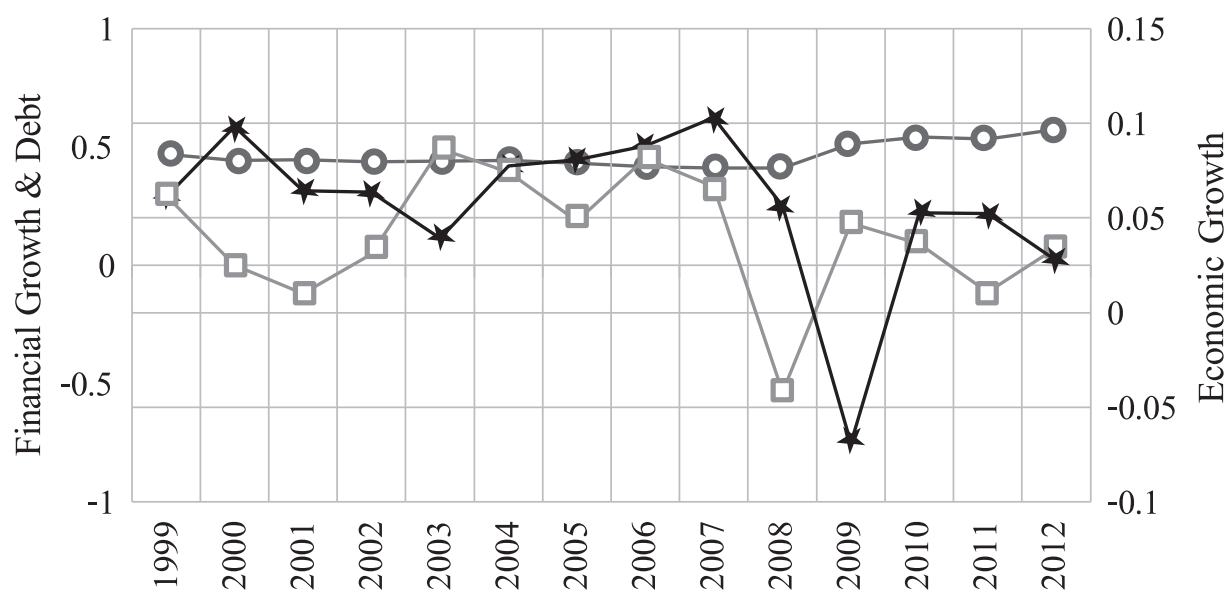

- - Financial Growth - - Debt (\% GDP) - - Economic Growth 
E. Debt $>90 \%$

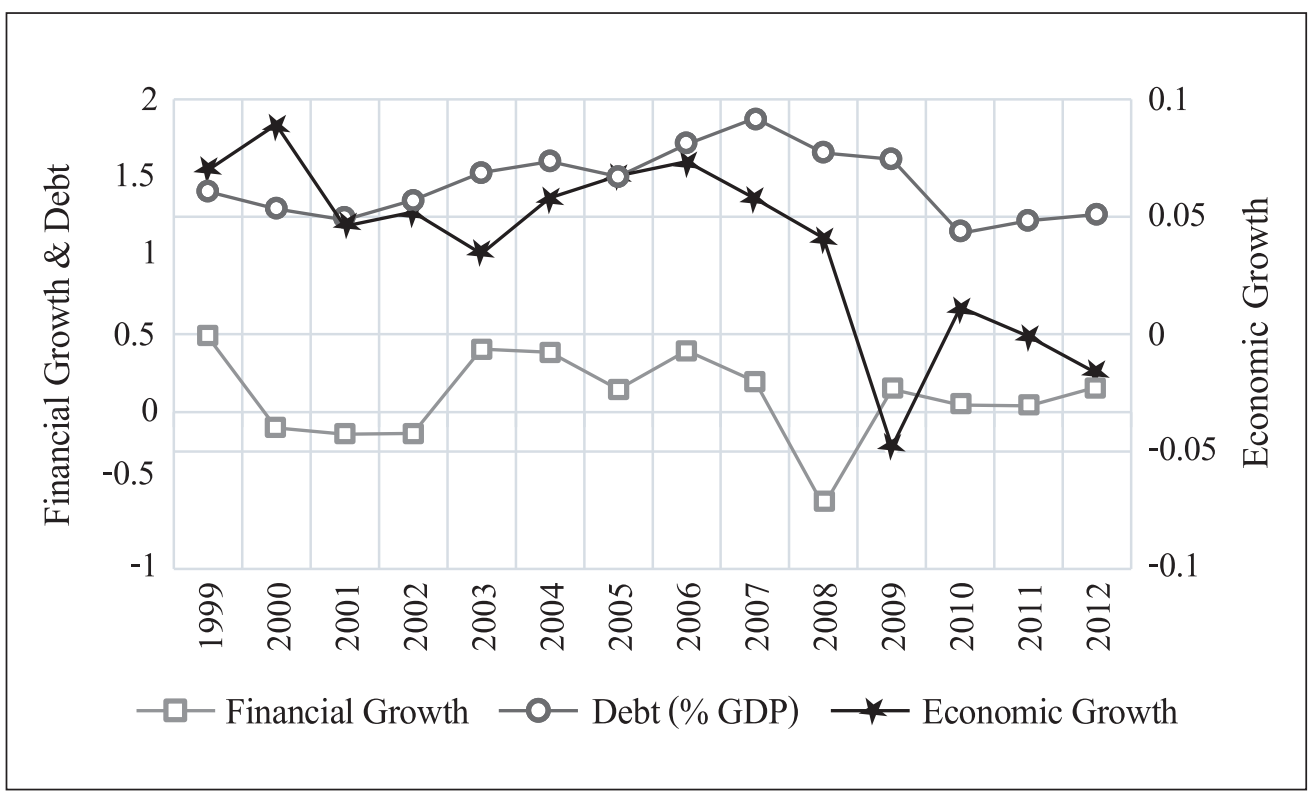

F

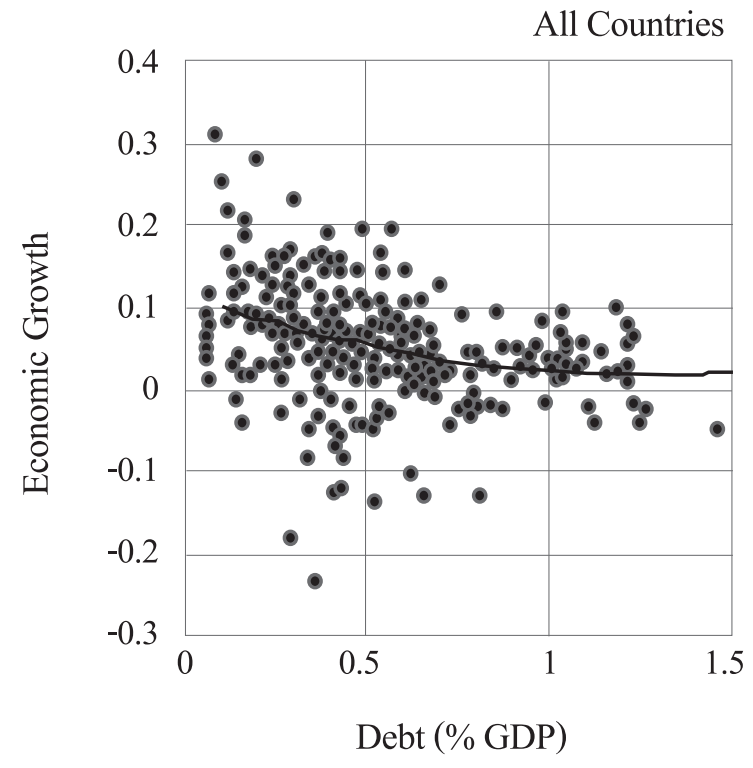


G

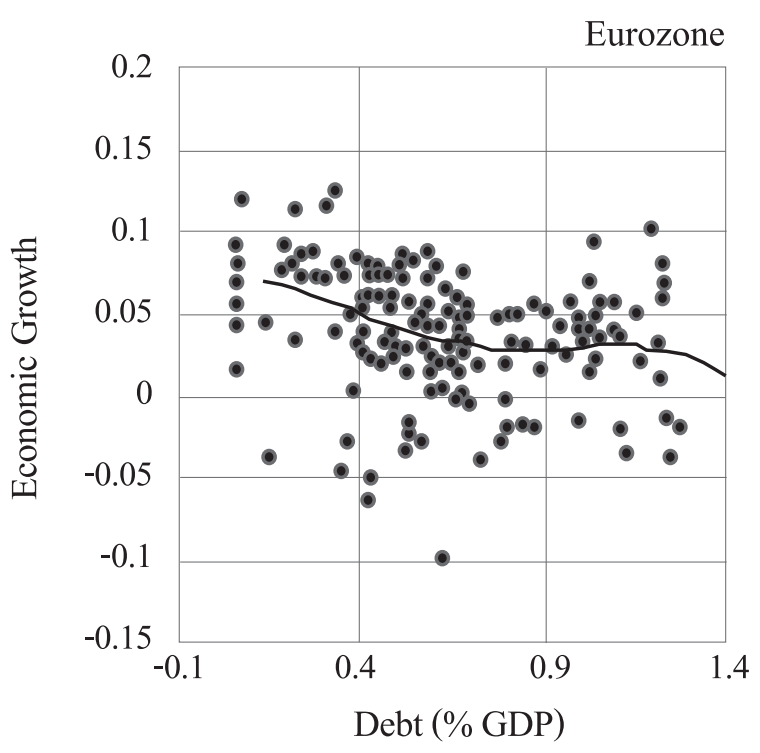

$\mathrm{H}$

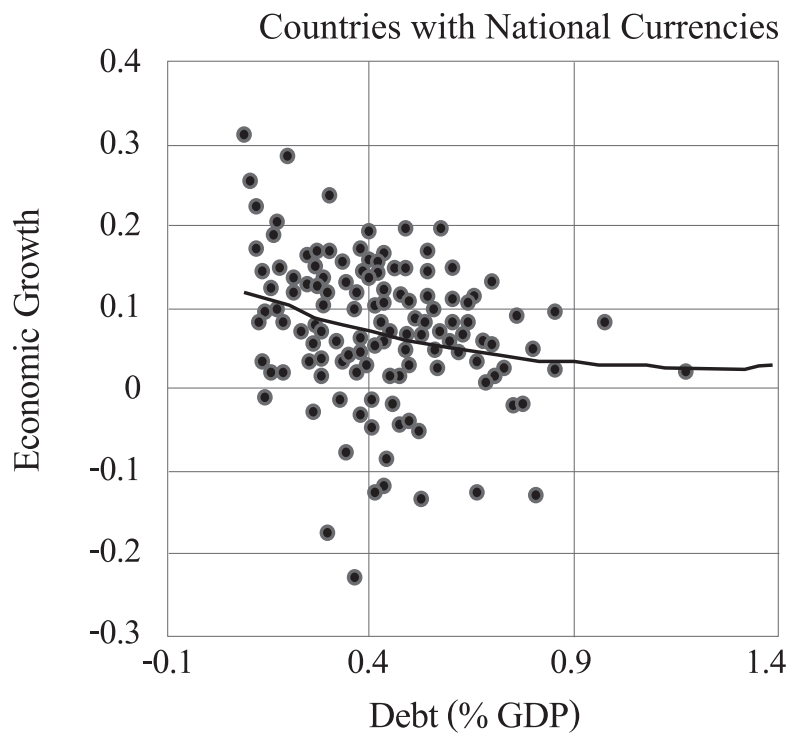

(Note) The first two columns of Figure 3 present the average financial and economic growths, as well as the average level of depth over the sample period, dissected into two sub-samples; countries that have adopted the Euro and countries that have not, as well countries with debt levels higher than $90 \%$ and countries with less than $90 \%$. The last column links economic growth and debt levels across the sample, under national currencies and in the Eurozone. 


\section{Bear versus bull market and debt}

Another observation refers to the nature of the link. Panel A-E show that changes in economic growth are mostly observed after financial growth sparks. This shows that changes in GDP influence market expectations, which seem to precede any changes in economic growth. There is a notable bull market period starting around 2000, followed by a strong bear market period after 2008. The link between financial and economic growths seems to strengthen significantly around 2008, and MCAP notably captures subsequent GDP changes, especially in the Eurozone. This shows that the markets discount timely information about economic growth. Consequently, the dynamic structure chosen to investigate the direction of the relationship in Equation (2.a), Equation (2.b), and Equation (2.c) seems to be justified.

Panel D and Panel E focus on countries with public debt levels beyond $90 \%$ of their respective GDPs. During bull markets, economic growth in such countries is more moderate, about 5-6\% p.a., compared with countries with lower debt, where it is about 6-10\% p.a.. Economic growth decreases significantly for debt-ridden countries during bear markets. Panel F-H distinguish between Eurozone and non-Eurozone countries. Panel $\mathrm{F}$ shows that, overall, higher borrowing is associated with exponentially lower economic growth. According to Panel $\mathrm{H}$, this is consistent in non-Eurozone countries. In contrast, countries that have adopted the Euro still appear to be able to achieve higher economic growth. The Euro seems to improve access to financing, which can further boost growth. Investigating this further, Figure 4 presents the relationship between the endogenous variables before and after the onset of the financial crisis in 2008. The first column confirms previous findings. However, Panel F and Panel J show that after 2008, the countries that did not join the Eurozone exhibit significantly lower growth across greater financial activity. Furthermore, Panel E and Panel H show that the link between financial and economic growths is significantly stronger in a bearish market, though it does not disappear after a macroeconomic shock. 
Figure 4. Economic growth, financial growth and debt levels: Inter-relations

A. All Countries

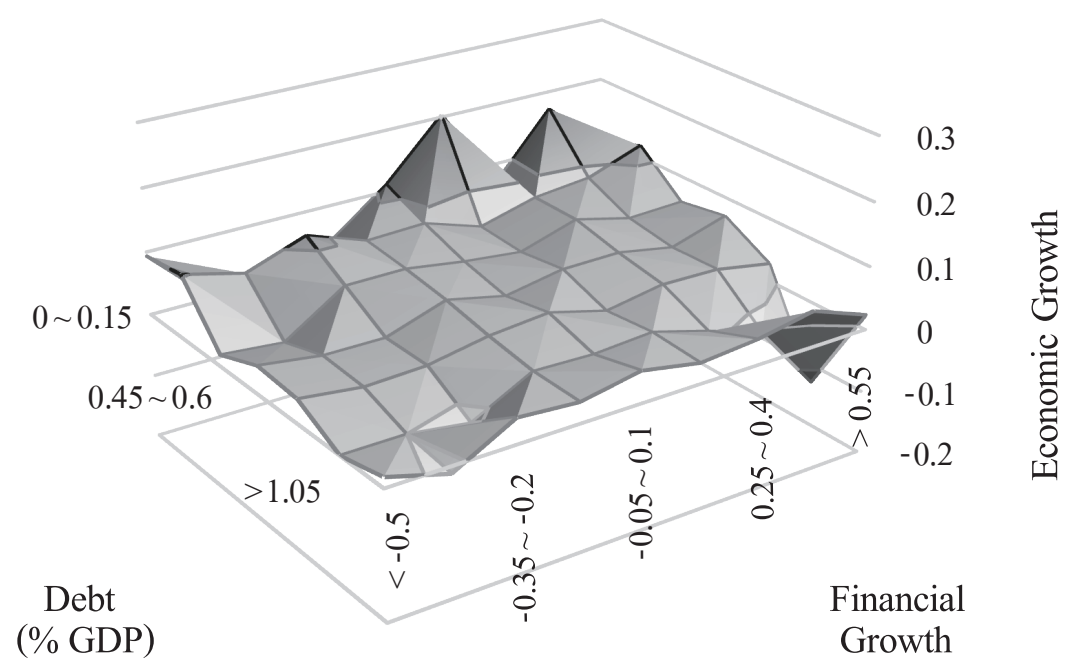

B. Eurozone

Debt

(\% GDP)

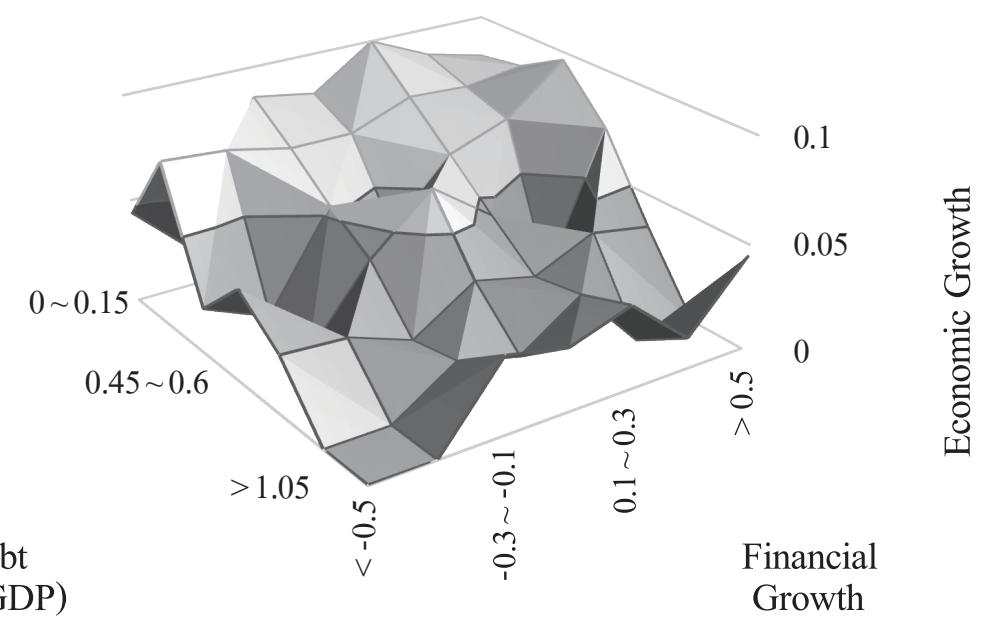




\section{Countries with national currencies}

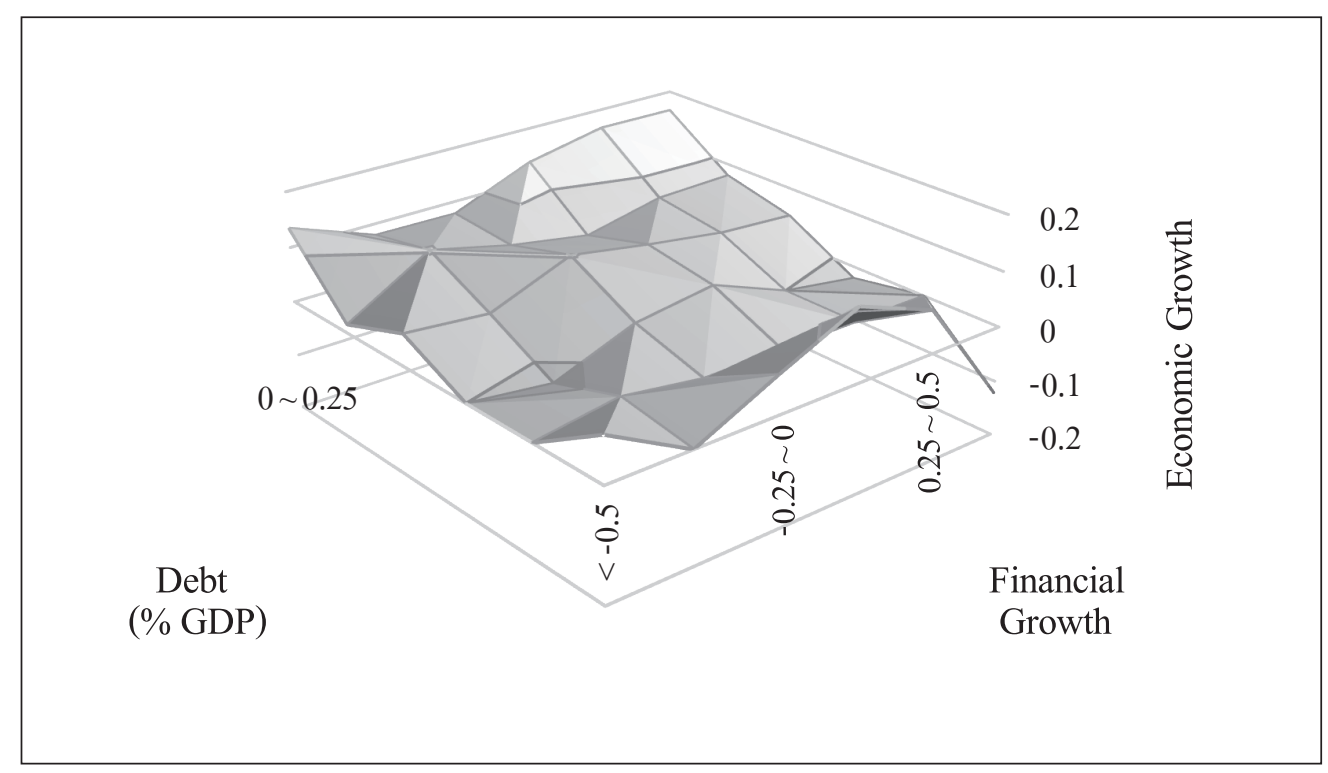

D. All Countries-Before financial crisis

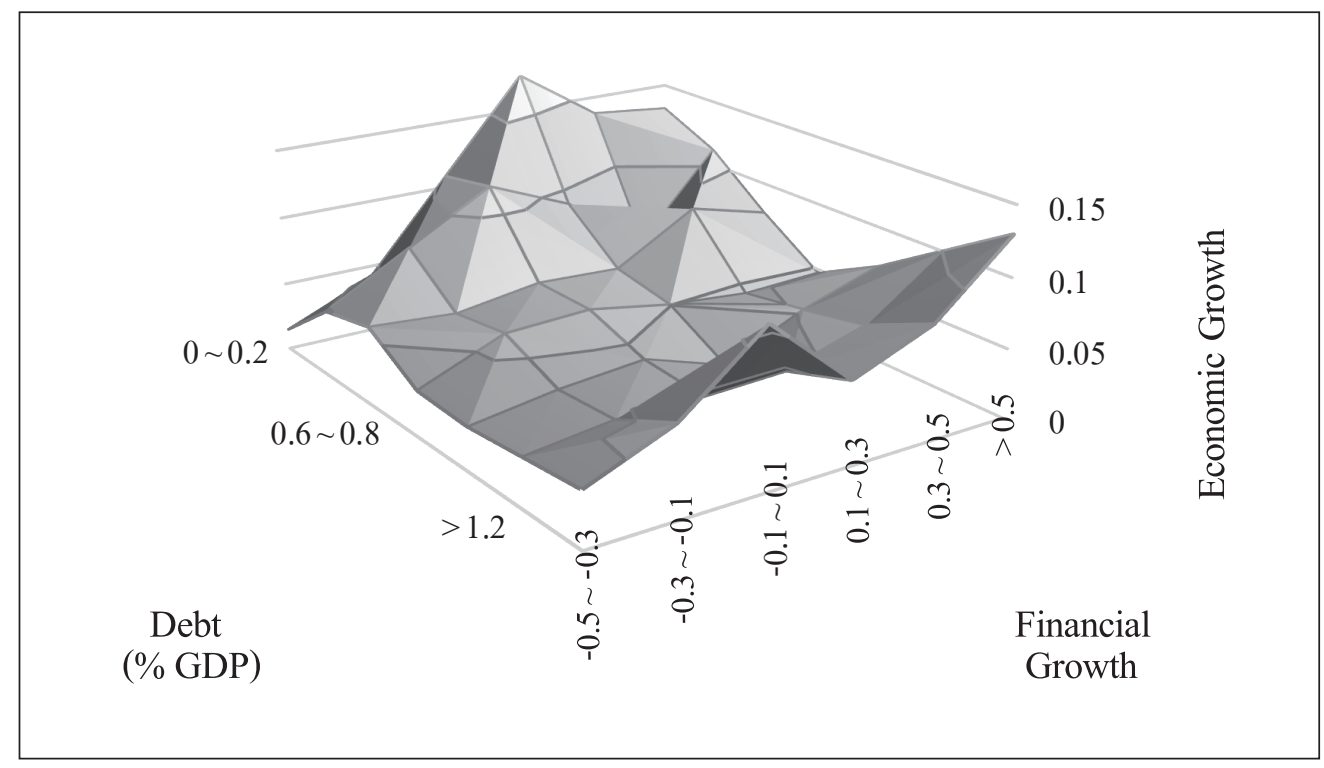




\section{E. Eurozone-Before financial crisis}

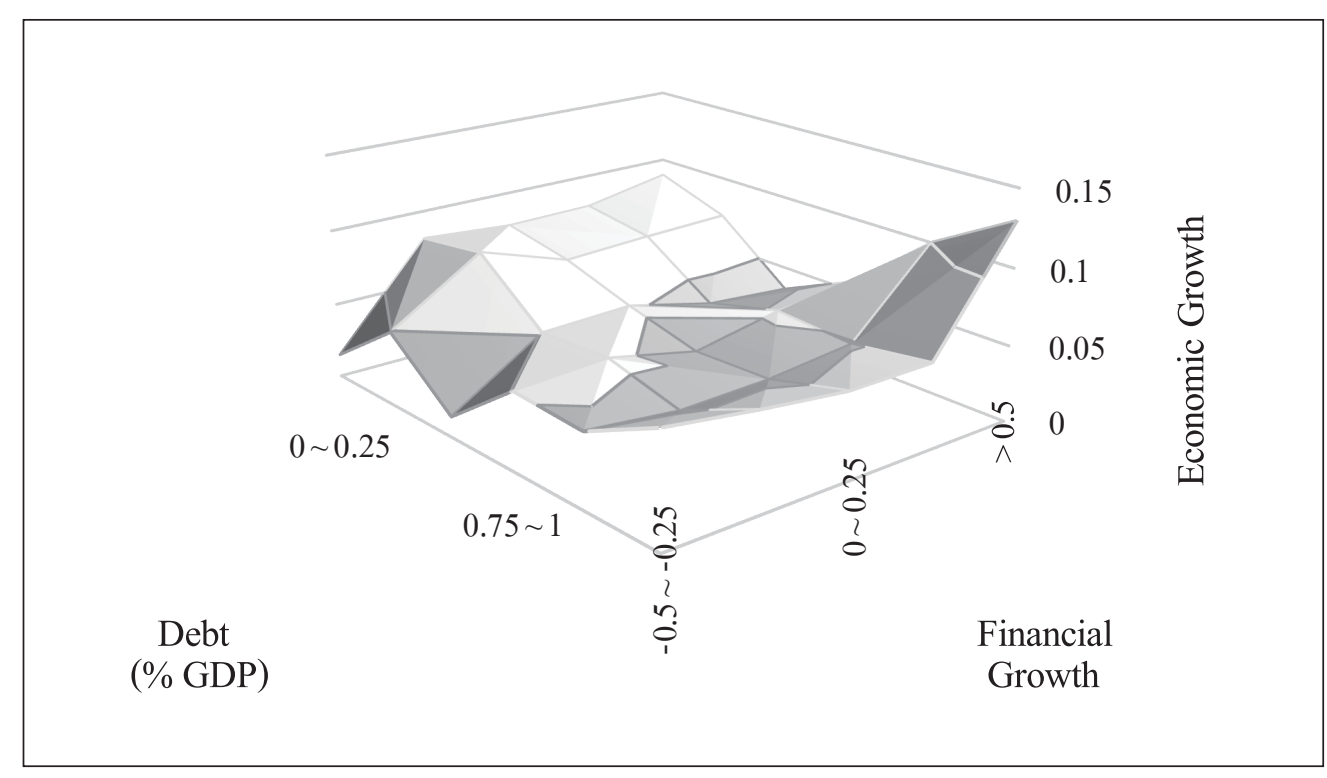

F. Countries with national currencies-Before financial crisis

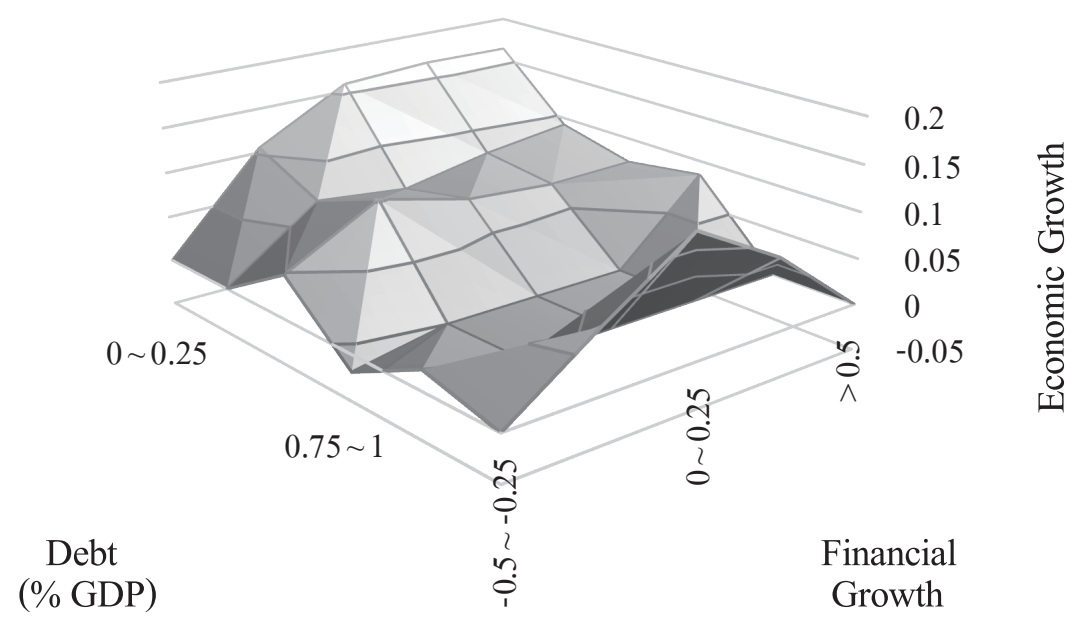




\section{G. All Countries-After financial crisis}

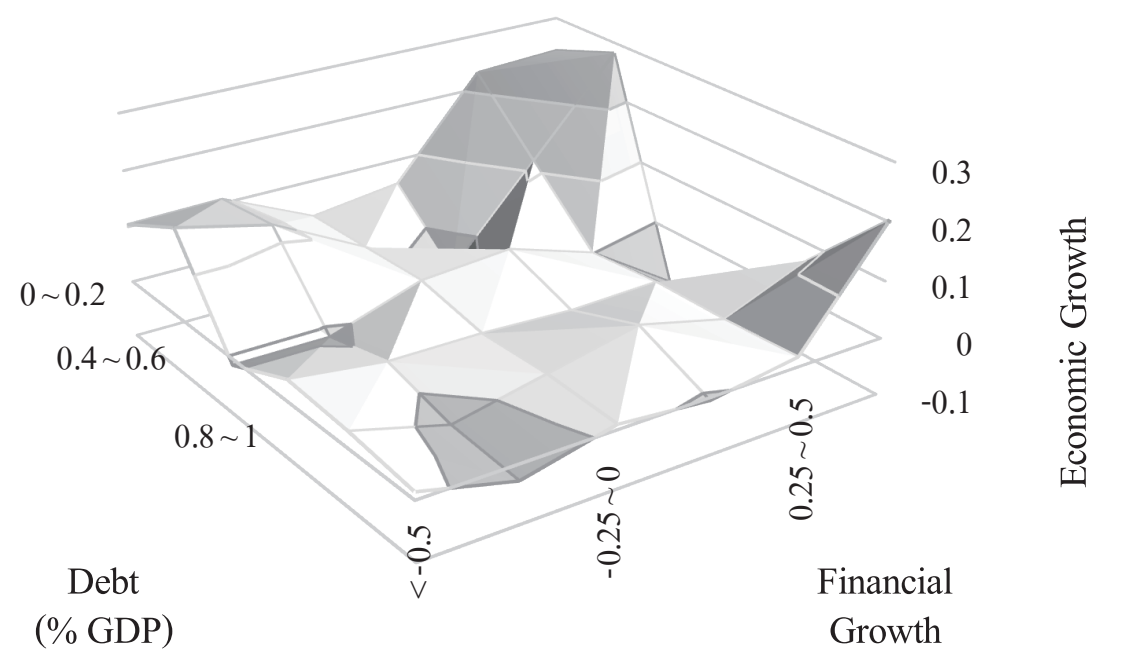

H. Eurozone-After financial crisis

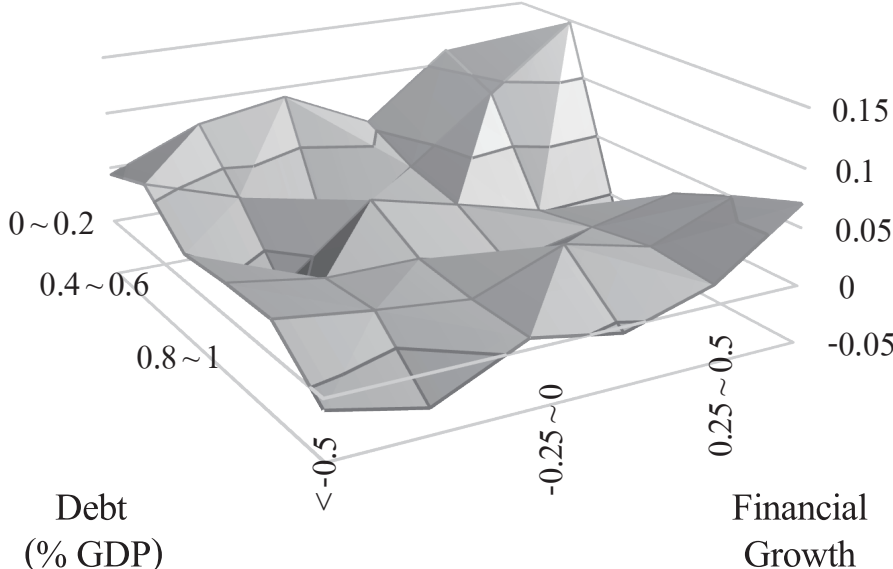


I. Countries with national currencies-After financial crisis

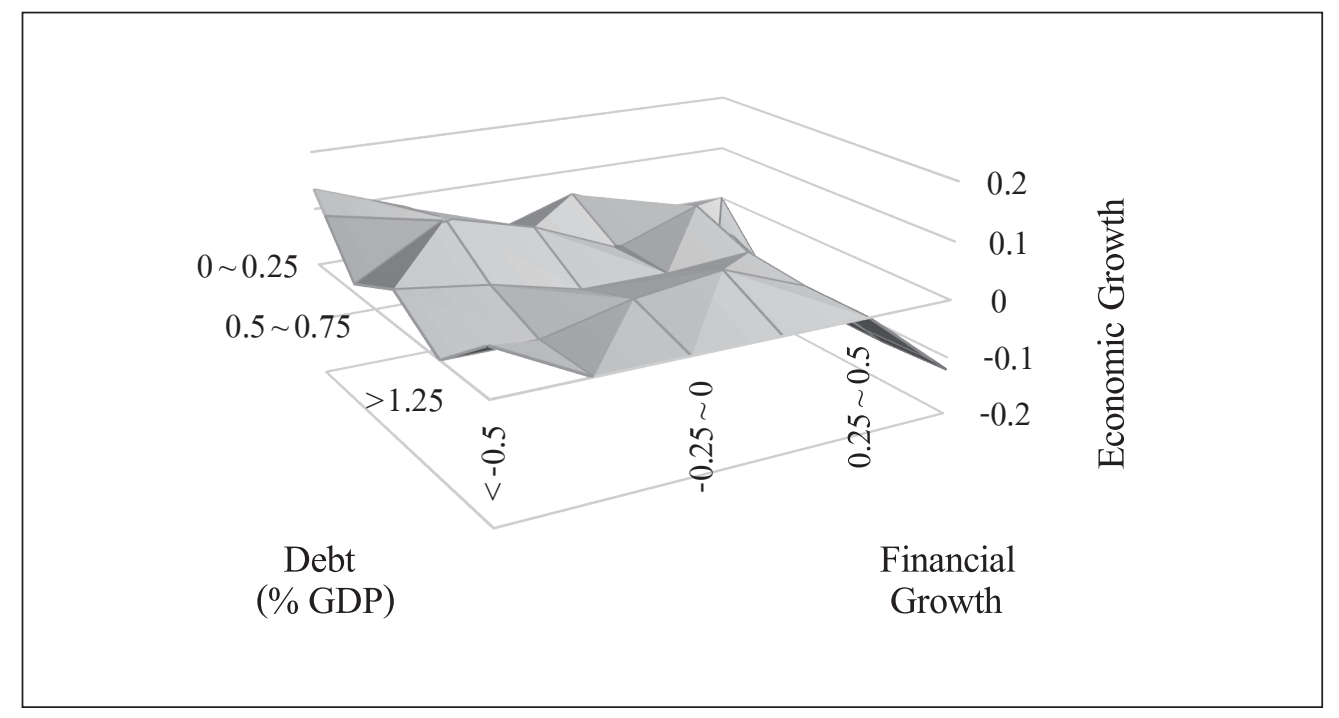

(Note) Figure 4 presents the average economic growth across different levels of debt and financial growth for all countries, i.e., Eurozone countries and countries with national currencies. The subsamples are further dissected into the periods prior to and after 2008.

\section{B. Parametric analysis}

\section{Financial growth and economic growth}

Table 1 presents the estimation results of the model presented in Equation (2.a), Equation (2.b), and Equation (2.c.) Focusing on the full sample, no significant link is observed between financial and economic growths in non-Eurozone countries. The highest absolute value of $t$-statistic is 1.67 , showing that the two figures are rather independent. However, financial growth appears to have a significant increasing effect on economic growth in countries that have adopted the Euro $\left(F G^{*} E\right.$ is 0.0311 and the $t$-statistic is 2.53). In parallel, looking at the determinants of financial growth, a significant (2.04) coefficient of 0.8012 for the $E U$ dummy shows that $G$ has an increasing impact on financial growth for countries that have joined the EU. This effect is found to be stronger for countries that have joined the Euro (coefficient is 0.3015 and $t$-statistic is 3.13). Consequently, a link between the two figures is present in Europe; they are found to be endogenous in the Eurozone but not necessarily within the EU.

In addition, political integration does not appear to exert any significant direct 
impact on either of the figures, since the coefficient of the $E U$ dummy remains rather insignificant. In contrast, a significant (3.01) coefficient of 0.7433 on the $E$ dummy shows that monetary integration seems to accelerate financial growth only, without any significant effect on economic growth. 


\begin{tabular}{|c|c|c|c|c|c|c|c|c|c|c|c|c|}
\hline \multirow{5}{*}{ 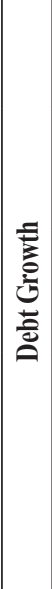 } & 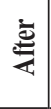 & 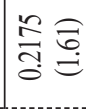 & $\begin{array}{l}\frac{\partial}{\partial} \\
\stackrel{\sigma}{\Xi}\end{array}$ & & 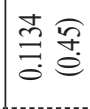 & $\begin{array}{l}\infty \\
\infty \\
0 \\
0 \\
i \\
i\end{array}$ & & 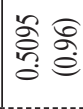 & : & & & \\
\hline & \multirow{2}{*}{ 苞 } & ণ্ণ & 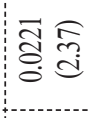 & & 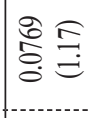 & 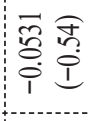 & & 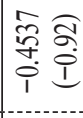 & 於 & & & \\
\hline & & 守 & $\begin{array}{l}\stackrel{\curvearrowright}{\circ} \\
\stackrel{\alpha}{d}\end{array}$ & $\stackrel{\infty}{\stackrel{0}{0}} \underset{0}{\stackrel{\sigma}{\Xi}}$ & 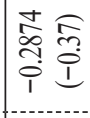 & 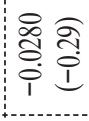 & 흘 & 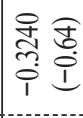 & 융 & 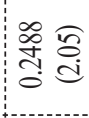 & & \\
\hline & \multirow{2}{*}{ ज्ञّँ } & 胥 & $\frac{\sigma}{\partial} \frac{E}{d}$ & & 容 & 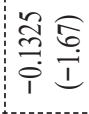 & & 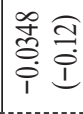 & 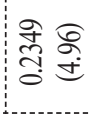 & & & \\
\hline & & 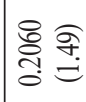 & $\begin{array}{l}\infty \\
\stackrel{0}{0} \\
0\end{array}$ & $\begin{array}{l}\text { 于 } \\
\stackrel{\infty}{\circ} \stackrel{\infty}{\Xi}\end{array}$ & 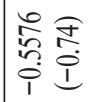 & 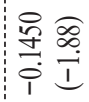 & 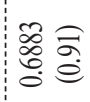 & 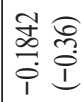 & 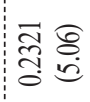 & 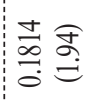 & & \\
\hline \multirow{5}{*}{ 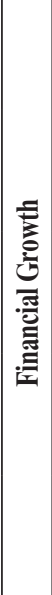 } & 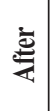 & 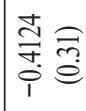 & 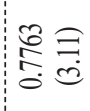 & & & & & 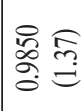 & 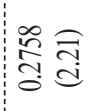 & & 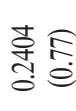 & 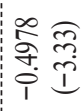 \\
\hline & \multirow{2}{*}{ 离 } & 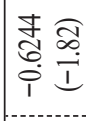 & 긍 & & & & & 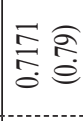 & 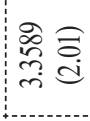 & & $\begin{array}{l}\stackrel{\circ}{a} \\
\vec{a} \\
0\end{array}$ & 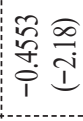 \\
\hline & & 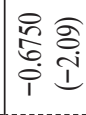 & $\begin{array}{l}\stackrel{\sigma}{\sigma} \\
\hat{\sigma} \\
\hat{\sigma}\end{array}$ & 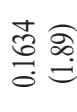 & & & & 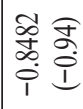 & 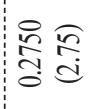 & $\begin{array}{l}\infty \\
\stackrel{\infty}{\sigma} \\
\stackrel{d}{d}\end{array}$ & 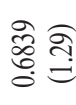 & 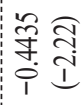 \\
\hline & \multirow[t]{2}{*}{ స్ } & 象 & 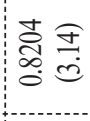 & & & & & $\underset{\substack{0 \\
2}}{\stackrel{2}{2}}$ & 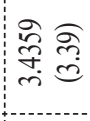 & & $\begin{array}{l}8 \\
0 \\
0\end{array}$ & $\begin{array}{l}\text { 足 } \\
0 \\
0 \\
1 \\
1 \\
0\end{array}$ \\
\hline & & 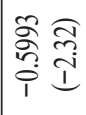 & 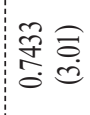 & $\left\{\begin{array}{l}\stackrel{f}{\Phi} \\
\stackrel{5}{G}\end{array}\right.$ & & & & 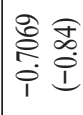 & 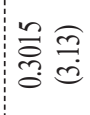 & 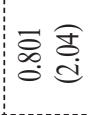 & $\begin{array}{l}\infty \\
0 \\
0 \\
0 \\
0\end{array}$ & 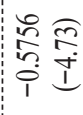 \\
\hline \multirow{5}{*}{ 言 } & 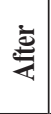 & 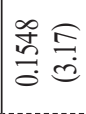 & 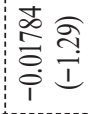 & & 离 & $\begin{array}{l}\infty \\
\stackrel{0}{6} \\
i \\
i\end{array}$ & & & & & 克 & $\begin{array}{c}\stackrel{0}{\mathbb{C}} \\
\stackrel{i}{I} \\
i\end{array}$ \\
\hline & \multirow{2}{*}{ 离 } & $\begin{array}{l}\widetilde{\sigma} \\
\stackrel{\sigma}{\sigma} \\
\stackrel{+}{+}\end{array}$ & 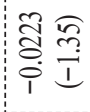 & & 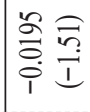 & 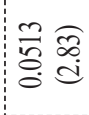 & & & & & 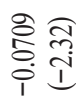 & 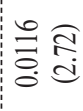 \\
\hline & & 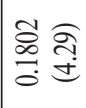 & 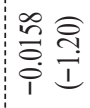 & 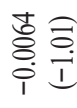 & $\mid \begin{array}{ll}n & 0 \\
0 & 0 \\
0 & 1 \\
1 & 1\end{array}$ & 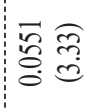 & 亭 & & & & $\begin{array}{ll}n & 0 \\
0 & 0 \\
0 & 0 \\
1 & i\end{array}$ & 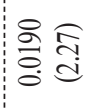 \\
\hline & \multirow[t]{2}{*}{ 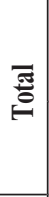 } & 尽 & 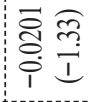 & & 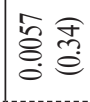 & 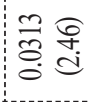 & & & & & 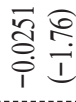 & $\begin{array}{l}\stackrel{ }{8} \\
0\end{array}$ \\
\hline & & 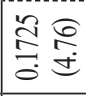 & $\begin{array}{l}\stackrel{0}{f} \\
\stackrel{1}{I} \\
\end{array}$ & $\begin{array}{l}0 \\
0 \\
0 \\
0 \\
1\end{array}$ & $\begin{array}{ll}\overline{8} & 6 \\
0 & 1 \\
1 & 1\end{array}$ & 疍 & 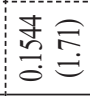 & & & & $\begin{array}{l}0 \\
5 \\
0 \\
0 \\
1 \\
1\end{array}$ & 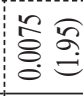 \\
\hline & & $\begin{array}{l}\text { 芯 } \\
\text { 芯 }\end{array}$ & 吉 & 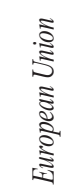 & 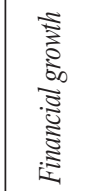 & 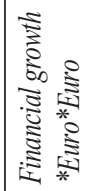 & 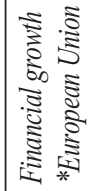 & है & 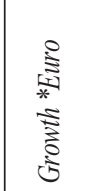 & 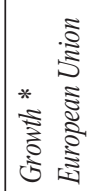 & $\stackrel{\Xi}{\square}$ & 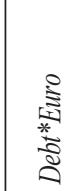 \\
\hline
\end{tabular}




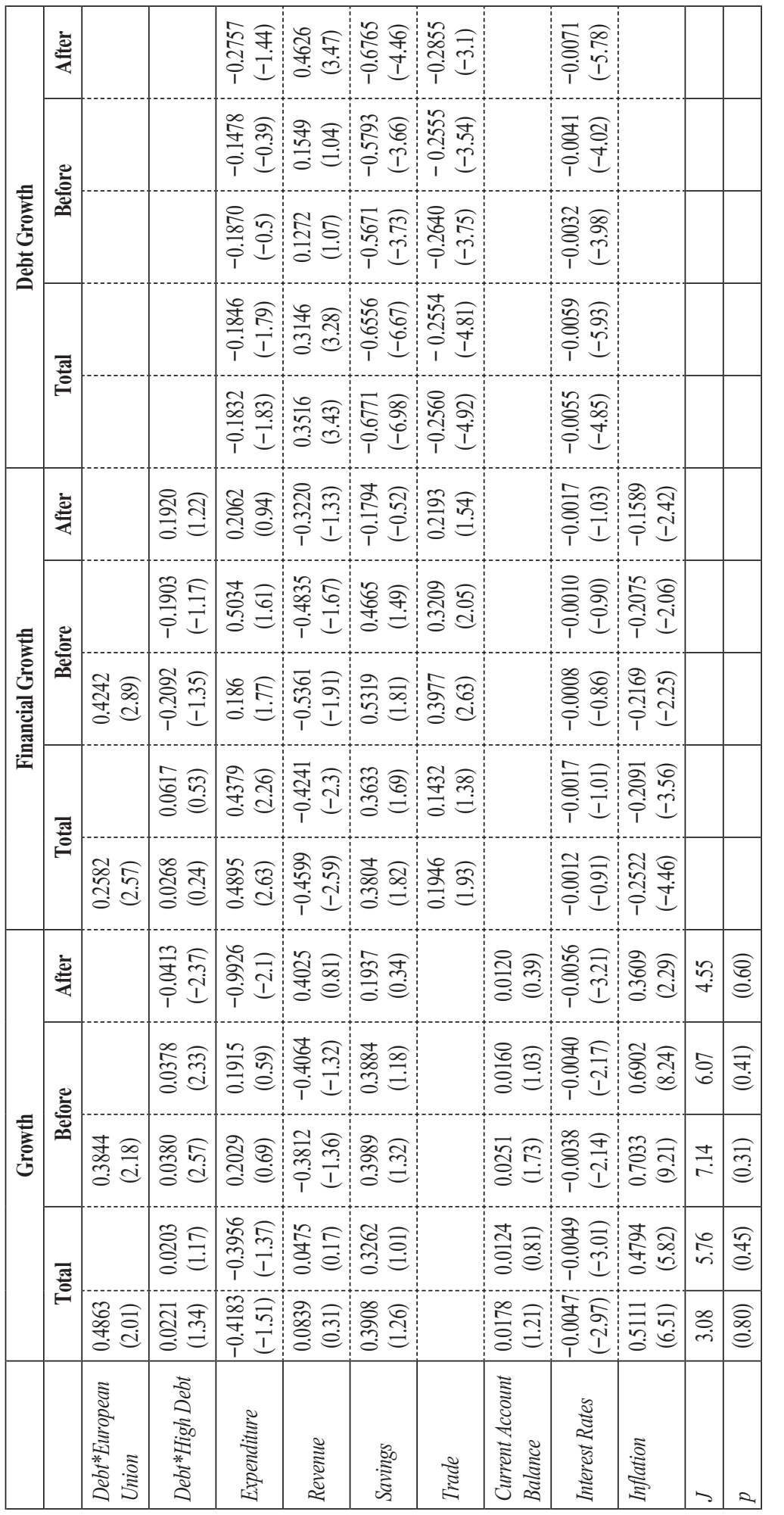

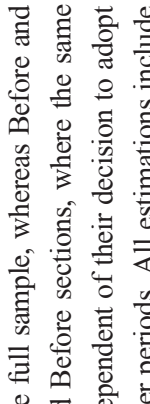

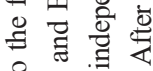

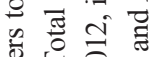

总完

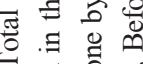

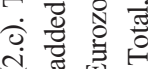

의

产䒠

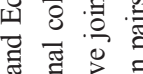

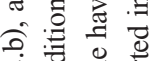

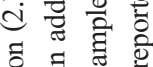

<

항

-

这是

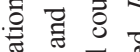

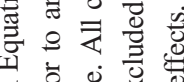

$\because$.

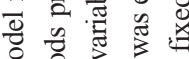

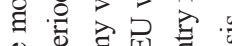

을 至

范 春

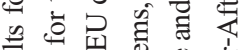

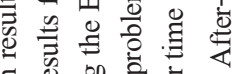

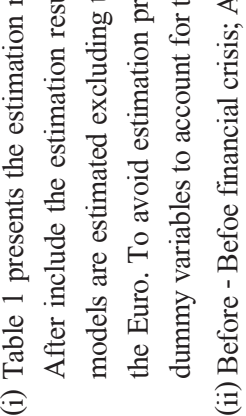

क्षै 
A possible explanation for this finding could depend on the existence of the EU, particularly the Eurozone. The EU is significantly larger than any single country and is therefore likely to be more resistant to market pressure than a single entity. Consequently, increased endogeneity between market conditions and fundamentals should be expected. Monetary integration appears to have increasing direct and indirect impacts on financial growth, which, in turn, further enhances economic growth, generating a spiral relationship. The absence of this link in the non-EU countries means the EU's contribution is significant. Given that $M C A P$ captures expectations, this contribution may be linked to increased confidence and therefore improved access to financing. Consequently, for a given change in $G D P$, markets react more positively in Eurozone member states, probably because investors anticipate lower exposure to macroeconomic risk. This allows investment flows that can further increase GDP.

However, this spiral effect does not seem to be consistent outside the Eurozone, not even in other (non-Euro) member states. EU membership would assist countries with positive $G D P$ changes to further increase their total market value, but such increased market value has no further impact on GDP unless the country has also joined the Euro. From a market perspective, this seems to be distinctively different from EU membership. Market participants seem to capitalize their expectations for future political stability and thus for lower macroeconomic risk on current prices when a country joins the EU. This might be derived from expectations regarding political or financial stability. However, this does not seem to be a sufficient condition to further increase their GDP; an increase would only occur if they also adopt the common currency. When they do adopt the Euro, they abandon their monetary tools; therefore, they need to have discipline when aiming to increase their competitive advantages. The fulfilment of these conditions, in combination with higher levels of political and monetary integrations, seems to lead to higher stability expectations, which, in turn, attract further economic development. This is the first sign that the Euro is suitable for countries that anticipate long-term gains from the spiral dynamic between financial and economic growths.

Moreover, this spiral link seems to be strongly present prior to 2008 but only within the Eurozone. GDP has an increasing impact on financial growth (e.g., $G^{*} E$ is 0.3589 and $t$-statistic is 2.01), which, in turn, further increases $G$ (e.g., $F G^{*} E$ is 0.0513 and $t$-statistic is 2.83). This shows that the Euro could accelerate economic growth in countries that can benefit from this spiral link. Again, only financial growth is found to be directly affected by monetary integration, while political integration is not found to have any significant direct impact on either variable. 
Furthermore, the Euro also appears to play a smoothing role during the period following the outbreak of the financial crisis. GDP improvements still increase market values but only within the Eurozone (e.g., $G^{*} E$ is 0.2758 and $t$-statistic is 2.21); however, the Eurozone countries now seem to be less exposed to market fluctuations. Specifically, an estimate of 0.1901 (2.60) shows that in non-Eurozone countries, GDP changes follow changes in market value. The mostly negative financial growth experienced during the post-2008 period appears to have a strong negative impact on these countries' economic growth. In contrast, a negative estimate for the Eurozone countries of $-0.1548(-2.09)$ indicates that this effect is milder for countries that have adopted the Euro. Negative financial growth still negatively affects economic growth, but the impact is considerably smaller in Eurozone member states. This indicates that non-Eurozone countries appear to be more exposed to market volatility after a macroeconomic shock than countries belonging to the monetary union. This highlights an additional beneficial impact of the Euro, which seems to abate the impact of macroeconomic shocks.

\section{Financial growth, economic growth and debt}

The previous section highlighted the Euro's contribution in accelerating both financial and economic growths, as well as their spiral dynamic. This influence of the Euro might be because of improved access to financing, which could be a major determinant of the spiral link. Equation (2.c) focuses on the impact of economic and financial growths on public debt growth, as well as on endogeneity issues.

The last section of Table 1 shows that monetary integration appears to have a significant impact on public borrowing levels. Eurozone member states exhibit significantly higher (e.g., 0.0248 with a $t$-statistic of 2.11) debt growth, both before (e.g., 0.1893 and $t$-statistic of 2.10) and after (e.g., 0.0199 and $t$-statistic of 1.99) 2008, while political integration does not exhibit any significant marginal impact. This is a sign of improved access to financing, probably as a result of additional confidence induced by monetary integration. This is further complemented when a member state experiences economic growth, but the same does not necessarily hold for financial growth. Specifically, a statistically significant difference in borrowing levels exists between member and non-member states. The impact of $G$ is insignificant for countries that have not joined the EU (e.g., coefficient is -0.1842 and $t$-statistic of -0.36), but it has a rather increasing impact for member states (e.g., 0.1814 and $t$-statistic of 1.94), especially when the Euro is the currency adopted (e.g., 0.2321 and $t$-statistic of 5.06). In contrast, no significant link appears to exist between financial growth and $D E B$. This shows that 
a country's fundamentals are more important than its financial profile in improving its borrowing position. Furthermore, the mostly insignificant coefficients of $E$ and $E U$ in the last column indicate that any Euro effect on borrowing becomes significantly less important during a bear market wherever financial commitments seem to be prioritised over economic development.

Now, we shift our focus to analyzing how the improved borrowing position (higher growth of debt accumulation) affects the spiral link between financial and economic growths. The first observation is derived from the third panel of the first section of Table 1. $D E B$ seems to be endogenous to GDP growth with differing impacts for member and non-member states. Higher debt growth seems to have a limiting impact on economic growth in countries that have not joined the Euro (e.g., coefficient is -0.5076 and $t$-statistics is -2.08). In contrast, the higher borrowing capacity of Euro member states seems to have an overall marginally positive impact on economic growth [e.g., 0.0075 (1.95) for $D E B^{*} E$ and 0.4863 (2.01) for $D E B^{*} E U$ ]. Consequently, the Euro appears to have another indirect positive impact on economic growth as Eurozone countries seem to have higher credibility that can be utilised to draw more funds, which can lead to further development.

However, there is a lack of consistency in the data before and after 2008. During the boom period prior to 2008, higher debt growth has a positive impact [e.g., 0.0190 (2.27)] on economic growth, even when debt exceeds 90\% of GDP [e.g., 0.0380 (2.57)]. In contrast, in the years following the sovereign bond crisis, increases in debt seem to significantly limit growth opportunities [e.g., $-0.0267(-2.77)]$ in the Eurozone, especially for countries with high borrowing levels [e.g., $-0.0413(-2.37)$ ]. This, along with the notable absence of Euro effects on debt, raises some concerns about the suitability or the overall impact of improved access to financing resulting from monetary integration. In the previous section, it was found that the Euro protects countries from erratic market movements by smoothing the negative impact of negative financial growth, but the limited monetary flexibility significantly dampens economic growth during a bear market. Improved access to financing might endogenously accelerate economic growth, but during bear market periods, financial obligations are prioritized and therefore the increased financing might be considered over-borrowing. In this case, it seems to reverse the spiral link between financial and economic growths and thus lead to recession.

Consequently, the benefits from the endogenous relationship between debt increases and economic growth are not unconditional. The Euro might assist member states achieve higher economic growth, but it might also lead them to take on unmanageable 
borrowing levels. This concern seems to be reflected in the impact of debt growth on financial growth. The third panel of the second section of Table 1 shows that higher $D E B$ consistently leads to lower marker values. This slows down the spiral effect of the endogenous economic and financial developments. However, this happens only in the Eurozone countries [e.g., $-0.5756(-4.73)]$ and not in member states that have not joined the Euro [e.g., 0.2582 (2.57)].

These findings lead to the conclusion that markets perceive the Euro to have a dual role. First, the Euro is found to have a beneficial impact by leading to an endogenous spiral link between financial and economic growths. However, this spiral link is bounded by borrowing levels. Positive debt growth might lead to higher growth during bull market conditions, but it reverses this spiral link during bear market conditions. This second role of the Euro has a rather limiting impact on economic growth, especially when the increase in financing is not accompanied by improvements in a country's fundamentals. The increased financing might improve GDP when the macroeconomic conditions allow for it, but it might also lead to unsustainable financing. This might constitute the foundations of what the literature considers to be bad growth. Countries can improve their access to financing by joining the monetary union, but unless resources are utilized efficiently in order to improve fundamentals, economic growth might be fragile and susceptible to volatile macroeconomic conditions.

Consequently, the suitability of adopting the Euro should depend on the ability of each country to benefit from the increased financing by engaging in the spiral endogenous link between financial and economic growths, which could eventually improve fundamentals. Excessive borrowing without engaging this link could lead to obviation of market confidence, which introduces an additional macroeconomic risk.

\section{Robustness}

The robustness of the empirical findings presented is tested by considering a potential long-term equilibrium among the endogenous variables by; (1) considering a different estimation method; and (2) testing the strength of the instrumental variables. Table 2 presents the estimation results for the model presented in Equation (2.a), Equation (2.b), and Equation (2.c). Parameters are estimated considering an error-correction specification, as well as using the Seemingly Unrelated Regression (SUR) method, which recognizes potential cross-correlations assuming that the innovations of the system are i.i.d.

Specifically, the bottom panel of Table 1 reports that all variables employed in the 
model are stationary, whereas the bottom part of Table 3 reports that the residuals of the full-sample estimation (Total in Table 1) are also stationary and non-heteroskedastic (cross-sectionally or over time). This indicates that the three endogenous variables might be cointegrated, exhibiting a long-term equilibrium relationship. The first three columns of Table 2 present the estimates of the parameters of the model in Equation (2.a), Equation (2.b), and Equation (2.c) with an error correction term. The error correction term is the lagged residual of the GDP regressed on a constant, MCAP, and Debt (all values are logged). The cointegration term is a significant determinant of economic and financial growths but not of debt growth. This indicates that MCAP and GDP are strongly linked to each other following a long-term equilibrium, whereas Debt only indirectly affects their growth. The presence of the cointegration term, as well as the different estimation method, produces consistent estimates with the GMM estimation (Table 1).

Furthermore, Table 3 presents the correlations between the regressors and the instrumental variables, which are the first lag of the regressors. The instruments appear to be highly correlated with the corresponding regressors and uncorrelated with the GMM residuals. Finally, the cross-correlation between the GMM residuals appears to be rather small.

\section{Table 2. Robustness test}

\begin{tabular}{|c|c|c|c|c|c|c|}
\hline & \multicolumn{3}{|c|}{ Equilibrium (GMM) } & \multicolumn{3}{|c|}{ SUR Estimation } \\
\hline & Growth & $\begin{array}{c}\text { Financial } \\
\text { growth }\end{array}$ & Debt & Growth & $\begin{array}{l}\text { Financial } \\
\text { growth }\end{array}$ & Debt \\
\hline Intercept & $\begin{array}{c}0.1395 \\
(5.16)\end{array}$ & $\begin{array}{l}-0.4221 \\
(1.99)\end{array}$ & $\begin{array}{l}0.2257 \\
(1.54)\end{array}$ & $\begin{array}{c}0.1624 \\
(5.11)\end{array}$ & $\begin{array}{c}-0.4476 \\
(-2.14)\end{array}$ & $\begin{array}{l}0.2136 \\
(1.64)\end{array}$ \\
\hline Euro & $\begin{array}{c}-0.0478 \\
(-1.96)\end{array}$ & $\begin{array}{c}-0.1591 \\
(-2.64)\end{array}$ & $\begin{array}{c}0.1423 \\
(3.36)\end{array}$ & $\begin{array}{c}-0.0491 \\
(-1.91)\end{array}$ & $\begin{array}{l}0.6395 \\
(3.46)\end{array}$ & $\begin{array}{l}0.0193 \\
(3.61)\end{array}$ \\
\hline European Union & $\begin{array}{c}-0.0045 \\
(-0.23)\end{array}$ & $\begin{array}{c}-0.0026 \\
(-1.56)\end{array}$ & $\begin{array}{c}-0.0433 \\
(0.66)\end{array}$ & $\begin{array}{c}-0.0050 \\
(-0.27)\end{array}$ & $\begin{array}{l}0.1720 \\
(-1.55)\end{array}$ & $\begin{array}{l}0.0160 \\
(1.73)\end{array}$ \\
\hline Financial growth & $\begin{array}{c}-1.0091 \\
(-1.38)\end{array}$ & & $\begin{array}{c}-0.0723 \\
(-0.69)\end{array}$ & $\begin{array}{c}-1.0604 \\
(-1.78)\end{array}$ & & $\begin{array}{r}-0.4281 \\
(-0.43)\end{array}$ \\
\hline $\begin{array}{c}\text { Financial } \\
\text { growth*Euro }{ }^{*} \text { Euro }\end{array}$ & $\begin{array}{c}0.0261 \\
(2.10)\end{array}$ & & $\begin{array}{l}-0.2315 \\
(-1.89)\end{array}$ & $\begin{array}{c}0.0302 \\
(2.36)\end{array}$ & & $\begin{array}{l}-0.2264 \\
(-1.92)\end{array}$ \\
\hline $\begin{array}{c}\text { Financial } \\
\text { growth*European } \\
\text { Union }\end{array}$ & $\begin{array}{c}0.0817 \\
(1.71)\end{array}$ & & $\begin{array}{c}0.2719 \\
(0.95)\end{array}$ & $\begin{array}{c}0.1641 \\
(1.85)\end{array}$ & & $\begin{array}{c}0.2640 \\
(0.97)\end{array}$ \\
\hline
\end{tabular}




\begin{tabular}{|c|c|c|c|c|c|c|}
\hline & \multicolumn{3}{|c|}{ Equilibrium (GMM) } & \multicolumn{3}{|c|}{ SUR Estimation } \\
\hline & Growth & $\begin{array}{c}\text { Financial } \\
\text { growth }\end{array}$ & Debt & Growth & $\begin{array}{c}\text { Financial } \\
\text { growth }\end{array}$ & Debt \\
\hline Growth & & $\begin{array}{c}-1.1429 \\
(-1.26)\end{array}$ & $\begin{array}{c}-0.0883 \\
(-0.45)\end{array}$ & & $\begin{array}{c}-0.9447 \\
(-0.56)\end{array}$ & $\begin{array}{c}-0.0674 \\
(-0.11)\end{array}$ \\
\hline Growth*Euro & & $\begin{array}{l}0.9257 \\
(2.06)\end{array}$ & $\begin{array}{l}0.3883 \\
(2.42)\end{array}$ & & $\begin{array}{c}0.6226 \\
(3.89)\end{array}$ & $\begin{array}{l}0.4319 \\
(3.38)\end{array}$ \\
\hline $\begin{array}{c}\text { Growth*European } \\
\text { Union }\end{array}$ & & $\begin{array}{l}0.6651 \\
(1.66)\end{array}$ & $\begin{array}{c}0.1343 \\
(0.50)\end{array}$ & & $\begin{array}{l}0.5089 \\
(2.38) \\
\end{array}$ & $\begin{array}{l}0.1441 \\
(1.65)\end{array}$ \\
\hline Debt & $\begin{array}{c}-0.0443 \\
(-1.75)\end{array}$ & $\begin{array}{c}0.4457 \\
(1.71)\end{array}$ & & $\begin{array}{c}-0.4195 \\
(-1.49)\end{array}$ & $\begin{array}{l}0.6429 \\
(1.17)\end{array}$ & \\
\hline Debt*Euro & $\begin{array}{l}0.0918 \\
(2.91)\end{array}$ & $\begin{array}{c}-0.1850 \\
(-2.33)\end{array}$ & & $\begin{array}{l}0.0959 \\
(3.19)\end{array}$ & $\begin{array}{c}-0.2280 \\
(-2.97)\end{array}$ & \\
\hline $\begin{array}{l}\text { Debt*European } \\
\text { Union }\end{array}$ & $\begin{array}{l}0.4115 \\
(2.46)\end{array}$ & $\begin{array}{l}0.8209 \\
(2.66)\end{array}$ & & $\begin{array}{l}0.4045 \\
(2.01)\end{array}$ & $\begin{array}{l}0.5764 \\
(2.59)\end{array}$ & \\
\hline Debt*High Debt & $\begin{array}{c}0.0092 \\
(1.41)\end{array}$ & $\begin{array}{c}0.1282 \\
(0.91)\end{array}$ & & $\begin{array}{l}0.0163 \\
(1.46)\end{array}$ & $\begin{array}{l}0.0921 \\
(0.91)\end{array}$ & \\
\hline Expenditure & $\begin{array}{c}-0.1492 \\
(-1.37)\end{array}$ & $\begin{array}{c}0.2456 \\
(1.82)\end{array}$ & $\begin{array}{c}-0.2893 \\
(-2.13)\end{array}$ & $\begin{array}{c}-0.2110 \\
(-1.33)\end{array}$ & $\begin{array}{l}0.2381 \\
(2.80)\end{array}$ & $\begin{array}{c}-0.2912 \\
(-1.75)\end{array}$ \\
\hline Revenue & $\begin{array}{l}0.1337 \\
(0.92)\end{array}$ & $\begin{array}{c}-0.1008 \\
(-2.58)\end{array}$ & $\begin{array}{c}0.4249 \\
(4.87)\end{array}$ & $\begin{array}{c}0.0904 \\
(1.41)\end{array}$ & $\begin{array}{c}-0.4752 \\
(-3.01)\end{array}$ & $\begin{array}{l}0.4258 \\
(5.06)\end{array}$ \\
\hline Savings & $\begin{array}{c}0.3400 \\
(2.05)\end{array}$ & $\begin{array}{c}0.1906 \\
(2.43)\end{array}$ & $\begin{array}{c}-0.7069 \\
(-7.51)\end{array}$ & $\begin{array}{l}0.3474 \\
(2.44)\end{array}$ & $\begin{array}{l}0.2562 \\
(2.26)\end{array}$ & $\begin{array}{c}-0.7103 \\
(-7.83)\end{array}$ \\
\hline Trade & & $\begin{array}{l}0.2757 \\
(1.76)\end{array}$ & $\begin{array}{c}-0.2821 \\
(-5.65)\end{array}$ & & $\begin{array}{l}0.1946 \\
(1.83)\end{array}$ & $\begin{array}{c}-0.2823 \\
(-5.86)\end{array}$ \\
\hline $\begin{array}{l}\text { Current Account } \\
\text { Balance } \\
\end{array}$ & $\begin{array}{l}0.0969 \\
(0.64)\end{array}$ & & & $\begin{array}{l}0.0369 \\
(1.26)\end{array}$ & & \\
\hline Interest Rates & $\begin{array}{c}-0.0043 \\
(-2.68)\end{array}$ & $\begin{array}{c}-0.0002 \\
(-0.01)\end{array}$ & $\begin{array}{c}-0.0067 \\
(-3.78)\end{array}$ & $\begin{array}{c}-0.0040 \\
(-2.73)\end{array}$ & $\begin{array}{c}-0.0001 \\
(-0.01)\end{array}$ & $\begin{array}{c}-0.0071 \\
(-4.43)\end{array}$ \\
\hline Inflation & $\begin{array}{l}0.4244 \\
(2.21)\end{array}$ & $\begin{array}{c}0.2141 \\
(2.27)\end{array}$ & & $\begin{array}{l}0.3093 \\
(3.71)\end{array}$ & $\begin{array}{c}-0.2109 \\
(-2.33)\end{array}$ & \\
\hline Co-integration & $\begin{array}{l}0.0181 \\
(2.89)\end{array}$ & $\begin{array}{l}0.1501 \\
(2.62)\end{array}$ & $\begin{array}{c}0.0086 \\
(0.37)\end{array}$ & & & \\
\hline $\begin{array}{l}J \\
p\end{array}$ & & $\begin{array}{c}2.38 \\
(0.88)\end{array}$ & & & & \\
\hline
\end{tabular}

(Note) Table 2 presents the estimation results of the model presented in Equation (2.a), Equation (2.b), and Equation (2.c), with two alternative methods. The next three columns present the estimation results employing the GMM method, where a cointegration term is added. The error correction term is computed as $u_{i, t}=\log (G D P)-c_{0}-c_{1} \log (M C A P)-c_{2} \log (D e b t)$. The following three columns present the estimation results employing the SUR method, where the residuals are allowed to be cross-correlated, but they are i.i.d overall. 


\begin{tabular}{|c|c|c|c|c|c|c|c|c|c|c|c|c|c|c|}
\hline 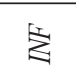 & & $\vec{\uparrow}$ & 8 & గొర & $\stackrel{ }{\circ}$ & స઼ & శి & $\stackrel{\Xi}{0}$ & $\bar{\Xi}$ & ${ }_{0}^{8}$ & $\frac{ \pm}{i}$ & $\stackrel{\infty}{\dot{\varphi}}$ & $\stackrel{8}{8}$ & ชి \\
\hline 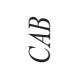 & & $\underset{i}{0}$ & $\begin{array}{l}0 \\
1\end{array}$ & 웅 & 6 & i. & $\approx$ & $\stackrel{\text { Oे }}{i}$ & $\overbrace{i}$ & $\ddot{\circ}$ & $\stackrel{0}{\circ}$ & $\stackrel{\square}{\circ}$ & 6 & \\
\hline $\begin{array}{l}\text { ry } \\
\text { à }\end{array}$ & $\infty$ & $\stackrel{\circ}{9}$ & స్ & $\frac{2}{0}$ & $\stackrel{\square}{\circ}$ & $\stackrel{7}{0}$ & $\frac{0}{0}$ & $\overline{0}$ & 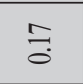 & 守 & $\infty$ & ঙั? & กิ & \\
\hline స్ & $\bar{P}$ & $\stackrel{\overbrace{}}{\hat{1}}$ & $\overrightarrow{\hat{\rho}}$ & $\overrightarrow{3}$ & 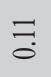 & $\stackrel{\infty}{0}$ & ते & ฮิ & ฮู & กิ & శี & $\underset{i}{\text { f. }}$ & $\overrightarrow{\hat{\varphi}}$ & \\
\hline 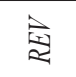 & ণి & $\stackrel{2}{0}$ & ㅎ. & $\frac{0}{9}$ & 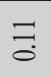 & $\overbrace{i}$ & $\stackrel{8}{\circ}$ & ठै. & ठே. & วิ & స్ & $\stackrel{\mathbb{Z}}{0}$ & $\stackrel{0}{0}$ & \\
\hline 疍 & శ్రి & $\stackrel{d}{\Delta}$ & $\check{\partial}$ & $\tilde{f}$ & ¿্. & ب0 & $\vec{\beth}$ & $\overline{\bar{i}}$ & $\frac{\nabla}{\dot{i}}$ & $\tilde{n}$ & If & 悹 & ป̊ & \\
\hline * & శ్రి & $\frac{9}{0}$ & $\stackrel{8}{8}$ & $\stackrel{\circ}{\circ}$ & సิ & $\stackrel{\circ}{\circ}$ & & $\stackrel{0}{\circ}$ & 음 & $\stackrel{\mathbb{S}}{0}$ & $\vec{\sigma}$ & $\ddot{0}$ & $\stackrel{8}{8}$ & \\
\hline 茎福 & $\stackrel{\infty}{0^{+}}$ & $\tilde{n}$ & $\overline{0}$ & के & สี & ठै. & 0 & iे & $\stackrel{0}{i}$ & ஓ. & $\stackrel{\circ}{\circ}$ & $\stackrel{\circ}{\circ}$ & $\stackrel{\infty}{\circ}$ & \\
\hline * : & ڤે & ت. & 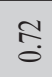 & 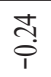 & ঙั & $\stackrel{\circ}{\delta}$ & $\stackrel{m}{0}$ & 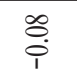 & $\underset{i}{\stackrel{?}{1}}$ & $\stackrel{\circ}{\circ}$ & à & $\stackrel{\infty}{\infty}$ & $\stackrel{\overbrace{}}{0}$ & \\
\hline ำ & $\stackrel{\infty}{\sigma}$ & $\overrightarrow{3}$ & $\vec{E}$ & 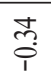 & $\bumpeq$ & & 6 & $\bar{i}$ & $\stackrel{\circ}{9}$ & gे & $\stackrel{t}{\circ}$ & $\stackrel{\infty}{\infty}$ & $\vec{\sigma}$ & \\
\hline 0 & $\stackrel{\infty}{i}$ & $\stackrel{n}{9}$ & gे & $\underset{\dot{\varphi}}{\dot{0}}$ & $\stackrel{m}{i}$ & $\stackrel{9}{9}$ & สิ & $\stackrel{0}{0}$ & $\stackrel{\overbrace{}}{0}$ & $\underset{1}{\stackrel{0}{0}}$ & $\stackrel{m}{\varphi}$ & $\frac{0}{0}$ & $\stackrel{8}{\circ}$ & \\
\hline 㐘它 & $\frac{0}{1}$ & $\underset{1}{0}$ & 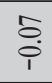 & $\stackrel{8}{\circ}$ & $\stackrel{\text { oे }}{0}$ & 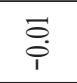 & $\stackrel{m}{0}$ & $\stackrel{\mathbb{Z}}{8}$ & $\frac{2}{0}$ & 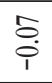 & ڤ్ & $\stackrel{0}{0}$ & $\begin{array}{l}\infty \\
0 \\
0 \\
1\end{array}$ & \\
\hline 诖 & $\because$ & $\frac{7}{0}$ & $\begin{array}{l}\infty \\
0 \\
\end{array}$ & $\stackrel{8}{8}$ & 0 & F & & $\stackrel{2}{\circ}$ & สี & $\stackrel{\infty}{0}$ & & $\underset{1}{\infty}$ & o. & \\
\hline $\int_{-1}^{\infty} 0$ & $\stackrel{\infty}{0}$ & $\stackrel{0}{\circ}$ & 8 & $\stackrel{n}{0}$ & $\stackrel{\circ}{\circ}$ & $\stackrel{2}{\circ}$ & $\tilde{0}$ & 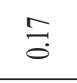 & శ్రి & $\overline{0}$ & $\stackrel{5}{0}$ & $\stackrel{0}{0}$ & 8 & \\
\hline * ن & $\stackrel{\infty}{c}$ & $\stackrel{\text { }}{\sigma}$ & $\dddot{\jmath}$ & 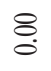 & 0 & $\vec{\Im}$ & & సે & $\vec{\Im}$ & ๙ิ & 0 & $\overline{\widehat{o}}$ & $\stackrel{\Delta}{d}$ & \\
\hline 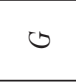 & 8 & $\overrightarrow{\hat{i}}$ & ڤ̊. & $\stackrel{n}{\circ}$ & के & $\stackrel{7}{0}$ & r & $\begin{array}{l}\stackrel{0}{0} \\
0\end{array}$ & $\overline{3}$ & ๙ุ̣ & กุ & ஜ্ & $\stackrel{0}{0}$ & \\
\hline 오 & గొ & $\stackrel{9}{0}$ & $\underset{-}{8}$ & ڤ્o & స్ & $\stackrel{\circ}{\circ}$ & $\underset{1}{g}$ & i. & oे & $\stackrel{\mathbb{S}}{\delta}$ & $\stackrel{尺}{\circ}$ & $\stackrel{\infty}{\circ}$ & $\stackrel{8}{-}$ & \\
\hline i & 于 & $\stackrel{\text { \$ }}{\circ}$ & $\begin{array}{l}0 \\
0 \\
0\end{array}$ & $\hat{\tilde{1}}$ & $\stackrel{d}{\Delta}$ & సે & 8 & $\stackrel{8}{\circ}$ & ț & $\approx$ & $\approx$ & $\tilde{n}$ & & \\
\hline Ex & $\stackrel{\circ}{\circ}$ & ถู & $\stackrel{\infty}{0}$ & $\underset{i}{\stackrel{+}{i}}$ & $\stackrel{\infty}{\circ}$ & 8 & $\mathrm{~T}$ & $\stackrel{\circ}{\circ}$ & $\stackrel{8}{8}$ & 3 & P & $\tilde{n}$ & 0 & \\
\hline & $\stackrel{8}{0}$ & $\stackrel{\infty}{\circ}$ & ț. & oे. & 을 & : & ฮૃ & 8 & 8 & స్తి & $\dot{0}$ & ฮิ & 0 & \\
\hline & $\varepsilon$ & ț. & : & 웅 & i̊. & $\frac{ \pm}{0}$ & రి & ¿ & 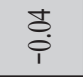 & 范 & ¿̊. & 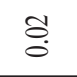 & $\stackrel{8}{\circ}$ & \\
\hline & 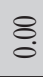 & $\stackrel{8}{\circ}$ & ö. & $\stackrel{2}{2}$ & $\stackrel{\leftrightarrow}{\circ}$ & $\stackrel{8}{\circ}$ & d़ & : & ช̊. & 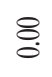 & Бे & $\stackrel{8}{8}$ & i & \\
\hline & 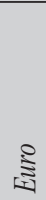 & 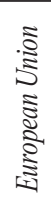 & 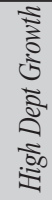 & है & 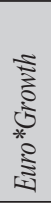 & 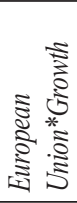 & 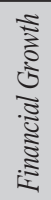 & 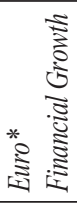 & 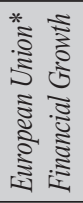 & $\vec{\Xi}$ & 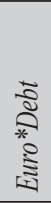 & 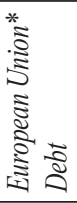 & 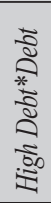 & 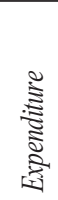 \\
\hline
\end{tabular}




\begin{tabular}{|c|c|c|c|c|c|c|c|c|c|c|c|c|}
\hline 㚆 & $\begin{array}{l}\text { Oे } \\
\end{array}$ & $\stackrel{8}{0}$ & ธิ & $\overline{0}$ & $\stackrel{n}{0}$ & & & & & & & \\
\hline త్రి & $\frac{9}{0}$ & $\stackrel{\infty}{0}$ & ठ̊. & $\stackrel{\circ}{\circ}$ & $\stackrel{\bar{i}}{\overline{1}}$ & & & & & & & \\
\hline $\begin{array}{l}\text { wy } \\
\text { 类 }\end{array}$ & $\stackrel{\infty}{i}$ & $\stackrel{\infty}{0}$ & $\stackrel{\circ}{\circ}$ & $\stackrel{2}{\circ}$ & $\overrightarrow{\widetilde{\sigma}}$ & & & & & & & \\
\hline $\overrightarrow{\text { ज्ञ }}$ & స్ & ஓ. & สิ & $\stackrel{\infty}{\circ}$ & $\stackrel{\text { oे }}{\text { i }}$ & & & & & & & \\
\hline 司 & s. & તุ & $\begin{array}{l}0 \\
0 \\
1\end{array}$ & $\widetilde{\widetilde{o}}$ & ஜ̊. & & & & & & & \\
\hline$\underset{1}{8}$ & $\stackrel{t}{\sigma}$ & $\widetilde{i}$ & ڤุ̣ & ஜ̊. & $\frac{n}{6}$ & & & & & & & \\
\hline 粪 & 5 & $\overrightarrow{\hat{q}}$ & กุ & $\underset{i}{ \pm}$ & $\stackrel{\overrightarrow{0}}{i}$ & & & & & & & \\
\hline 莕舟 & ్ㅗㅇ & in & $\underset{i}{?}$ & $\ddot{\circ}$ & ڤ్రి & & & & & & & \\
\hline * & ֻั & $\tilde{i}$ & $\tilde{\hat{i}}$ & $\stackrel{\infty}{\circ}$ & $\stackrel{\bar{i}}{\bar{i}}$ & & & & & & & \\
\hline 里 & สุ & के & 我 & $\stackrel{8}{\circ}$ & $\stackrel{\circ}{\stackrel{0}{0}}$ & & & & & & & \\
\hline نئ & $\stackrel{8}{0}$ & $\overrightarrow{\bar{i}}$ & $\stackrel{0}{0}$ & $\ddot{\circ}$ & $\stackrel{\overbrace{}}{\circ}$ & & & & & & & \\
\hline 必足 & $\begin{array}{l}0 \\
0 \\
1\end{array}$ & $\begin{array}{l}0 \\
0 \\
i \\
1\end{array}$ & $\stackrel{0}{\circ}$ & $\tilde{\circ}$ & $\ddot{\circ}$ & & & & & & & \\
\hline 勿 & $\begin{array}{l}0 \\
\hat{i} \\
1\end{array}$ & $\begin{array}{c}\hat{0} \\
\hat{i} \\
\end{array}$ & ?ृ. & ठ̊. & $\begin{array}{l}0 \\
0 \\
i \\
i\end{array}$ & & & & & & & \\
\hline ن & $\stackrel{0}{i}$ & $\stackrel{8}{\circ}$ & $\frac{7}{0}$ & $\ddot{\circ}$ & $\stackrel{7}{\div}$ & & & & & & & \\
\hline 㣰 & $\stackrel{n}{6}$ & $\ddot{\circ}$ & ț. & tே. & $\stackrel{m}{i}$ & & & & & & & \\
\hline ن & $\frac{9}{1}$ & $\stackrel{0}{0}$ & ฮิ & $\stackrel{\square}{\circ}$ & $\stackrel{ }{\circ}$ & & & & & & & \\
\hline 国 & $\stackrel{\infty}{0}$ & స్ి & $\stackrel{+}{\Delta}$ & $\stackrel{m}{9}$ & $\underset{i}{\vec{i}}$ & & & & & & & \\
\hline 谁 & $\stackrel{8}{\circ}$ & స్త & $\underset{1}{8}$ & $\underset{i}{0}$ & సิ & & & & & & & \\
\hline w & $\bar{\sigma}$ & 菅 & $\underset{1}{0}$ & oे & $\frac{9}{1}$ & & & & & & & \\
\hline $\mathrm{ur}^{\mathrm{m}}$ & ஜ̊. & $\underset{\mathrm{c}}{\mathrm{i}}$ & 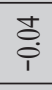 & $\stackrel{\text { Oे }}{0}$ & $\underset{0}{0}$ & $\begin{array}{l} \\
\\
\end{array}$ & $\stackrel{8}{0}$ & $\stackrel{8}{8}$ & & సે & ت્ & $\begin{array}{l}\text { तै } \\
\text { iे } \\
\end{array}$ \\
\hline wa & $\overrightarrow{0}$ & $\stackrel{0}{i}$ & ț & $\stackrel{8}{0}$ & $\stackrel{8}{8}$ & $\begin{array}{l} \\
\\
\\
\end{array}$ & $\stackrel{8}{-}$ & gे. & & 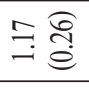 & ț & 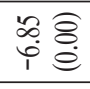 \\
\hline 约 & $\ddot{\circ}$ & o̊̀ & 苂 & $\stackrel{\square}{\circ}$ & i⿱宀 & $\underset{-}{8}$ & $\begin{array}{l}\dot{0} \\
\\
\end{array}$ & $\stackrel{+}{i}$ & & f. & ત્ન & $\begin{array}{l}\vec{\sigma} \\
+\stackrel{0}{e} \\
i\end{array}$ \\
\hline$I$ & 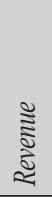 & 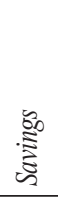 & छัँ & 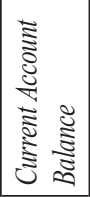 & $\frac{\bar{\Xi}}{\bar{\Xi}}$ & $\mathrm{rar}^{-}$ & $41^{2}$ & 近 & 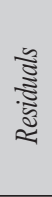 & 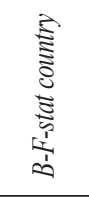 & 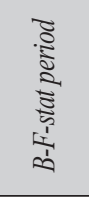 & 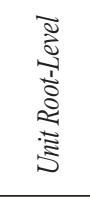 \\
\hline
\end{tabular}

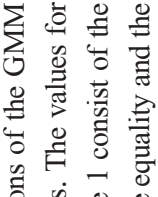

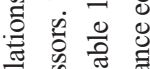

政

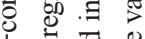

iे

ठै

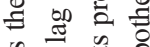

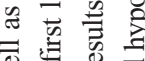

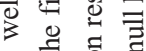

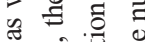

की .

है 䓎

可 产

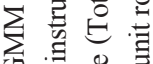

0

छ छ

击

की

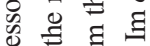

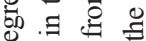

过 范

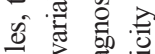

要

$>$ ज

तु

$\frac{2}{3}$

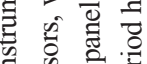

है

‡

区ี

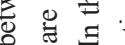

$\times$ पे

帚 吾

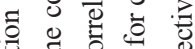

专 $\Xi$ i

范然造

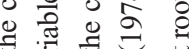

\#

牙

总

$m$ 离跑

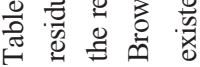

है 


\section{Conclusion}

In this study, we investigate the suitability of adopting the Euro by revisiting the interaction between financial and economic growths in Europe. We introduce the growth of public financing as an integral component and investigate endogeneity among all three factors. We also investigate potential differentials between the impact of political (EU) and financial (Eurozone) integrations.

The empirical findings indicate that neither political nor monetary integration exhibits any direct impact on economic growth. Instead, their impact is rather indirect through financial and debt growths. More specifically, monetary integration appears to allow countries to borrow more and accelerates financial growth, both directly and indirectly, through improvements in country fundamentals. Increased market values and improved financing further accelerate economic growth, indicating a spiral endogenous link between the three. However, this link is only observed within Eurozone member states, highlighting the existence of a Euro effect. This effect seems to be strong, especially during bear market conditions prior to 2008, when even countries with high debt balances were able to benefit from the spiral link and experience higher economic growth. In contrast, during the bearish market conditions in the post-2008 period, a sharp correction of market values and economic growth can be observed, especially for countries with high levels of debt. This reverses the aforementioned spiral link and leads to recession.

Consequently, the Euro is found to play a dual role. First, it has a positive indirect impact on economic growth by allowing the countries to engage in a spiral endogenous link between financial and economic growths, as well as debt. Improved access to financing allows for more investments, which increase GDP. This increases market values, which further boost economic growth. EU members that have not adopted the Euro can still draw marginally more funds upon higher economic growth, but the lack of the common currency fails to create the necessary confidence to trigger a synergetic endogeneity. However, this exuberance might lead countries to borrow more, introducing a moral hazard of over-borrowing. This second role of the Euro introduces a macroeconomic risk, wherein countries might pursue economic growth through an improved credit profile because of the monetary integration rather than through an improvement in country fundamentals. This might set the foundation for bad growth, which reverses the aforementioned spiral endogenous link after macroeconomic shocks, 
thereby leading to recession. Therefore, the interaction between the Euro's dual role, which is unique for each country, should be a major determinant of the suitability of adopting the common currency. On a larger scale, European policies should focus either on distinguishing between good and bad borrowing and therefore between good and bad growth, and further, should pay due attention to on structural changes that will allow countries to benefit from the financial-economic growth dynamic.

Received 5 October 2015, Revised 4 April 2016, Accepted 27 April 2016

\section{References}

Abiad, Abdul, Daniel Leigh, and Ashoka Mody. "Financial Integration, Capital Mobility, and Income Convergence." Economic Policy 24, no. 58 (April 2009): 241-305. doi:10.1111/j.1468-0327.2009.00222.x.

Adam, Christopher S., and David L. Bevan. "Fiscal Deficits and Growth in Developing Countries." Journal of Public Economics 89, no. 4 (April 2005): 571-97. doi:10.1016/ j.jpubeco.2004.02.006.

Aizenman, Joshua, Yeonho Lee, and Youngseop Rhee. "International Reserves Management and Capital Mobility in a Volatile World: Policy Considerations and a Case Study of Korea." Journal of the Japanese and International Economies 21, no. 1 (March 2007): 1-15. doi:10.1016/j.jjie.2005.12.001.

Alessi, Lucia, and Carsten Detken. "Quasi Real Time Early Warning Indicators for Costly Asset Price Boom/bust Cycles: A Role for Global Liquidity." European Journal of Political Economy 27, no. 3 (September 2011): 520-33. doi:10.1016/ j.ejpoleco.2011.01.003.

Alfaro, Laura, Areendam Chanda, Sebnem Kalemli-Ozcan, and Selin Sayek. "FDI and Economic Growth: The Role of Local Financial Markets." Journal of International Economics 64, no. 1 (October 2004): 89-112. doi:10.1016/s0022-1996(03)00081-3.

Allen, Franklin. "The Market for Information and the Origin of Financial Intermediation." Journal of Financial Intermediation 1, no. 1 (March 1990): 3-30. doi:10.1016/1042- 
9573(90)90006-2.

Allen, Franklin, and Douglas Gale. "Financial Markets, Intermediaries, and Intertemporal Smoothing.” Journal of Political Economy 105, no. 3 (June 1997): 52346. doi:10.1086/262081.

Alonso-Borrego, César, and Manuel Arellano. "Symmetrically Normalized InstrumentalVariable Estimation Using Panel Data.” Journal of Business \& Economic Statistics 17 (January 1996): 36-49.

Ang, James B., and Warwick J. McKibbin. "Financial Liberalization, Financial Sector Development and Growth: Evidence from Malaysia." Journal of Development Economics 84, no. 1 (September 2007): 215-33. doi:10.1016/j.jdeveco.2006.11.006.

Arellano, Manuel, and Stephen Bond. "Some Tests of Specification for Panel Data: Monte Carlo Evidence and an Application to Employment Equations." The Review of Economic Studies 58, no. 2 (April 1991): 277-97. doi:10.2307/2297968.

Arellano, Manuel, and Olympia Bover. "Another Look at the Instrumental Variable Estimation of Error-Components Models." Journal of Econometrics 68, no. 1 (July 1995): 29-51. doi:10.1016/0304-4076(94)01642-d.

Ariyoshi, Akira, Friedrich Habermeier, Andrei Ki, Jorge I. C Kriljenko, and Inci Otker. Capital Controls: Country Experiences with Their Use and Liberalization. United States: International Monetary Fund (IMF), 2000.

Aschauer, David Alan. "Public Capital and Economic Growth: Issues of Quantity, Finance, and Efficiency." Economic Development and Cultural Change 48, no. 2 (January 2000): 391-406. doi:10.1086/452464.

Bagehot, Walter. Lombard Street: A Description of the Money Market. Kegan, Paul \& Trench, 1983.

Bakker, Age, and Bryan Chapple. Advanced Country Experiences with Capital Account Liberalization. United States: International Monetary Fund (IMF), 2002.

Beck, T, A Demirguckunt, and V Maksimovic. "Financing Patterns around the World: Are Small Firms Different?" Journal of Financial Economics 89, no. 3 (September 2008): 467-87. doi:10.1016/j.jfineco.2007.10.005.

Beck, Thorsten, Ross Levine, and Norman Loayza. "Finance and the Sources of 
Growth." Journal of Financial Economics 58, no. 1-2 (January 2000): 261-300. doi:10.1016/s0304-405x(00)00072-6.

Beck, Thorsten, Mattias Lundberg, and Giovanni Majnoni. "Financial Intermediary Development and Growth Volatility: Do Intermediaries Dampen or Magnify Shocks?" Journal of International Money and Finance 25, no. 7 (November 2006): 1146-67. doi:10.1016/j.jimonfin.2006.08.004.

Beetsma, Roel, Massimo Giuliodori, Frank de Jong, and Daniel Widijanto. "Spread the News: The Impact of News on the European Sovereign Bond Markets during the Crisis." Journal of International Money and Finance 34 (April 2013): 83-101. doi:10.1016/ j.jimonfin.2012.11.005.

Beirne, John, and Marcel Fratzscher. "The Pricing of Sovereign Risk and Contagion during the European Sovereign Debt Crisis." Journal of International Money and Finance 34 (April 2013): 60-82. doi:10.1016/j.jimonfin.2012.11.004.

Berg, Andrew, Eduardo Borensztein, and Catherine A. Pattillo. "Assessing Early Warning Systems: How Have They Worked in Practice?” IMF Working Papers 04, no. 52 (2004): 1. doi:10.5089/9781451847284.001.

Berg, Andrew, and Anne O. Krueger. "Trade, Growth, and Poverty: A Selective Survey." IMF Working Papers 03, no. 30 (2003): 1. doi:10.5089/9781451844931.001.

Berglöf, Erik, Yevgeniya Korniyenko, Jeromin Zettelmeyer, and Alexander Plekhanov. "Understanding the Crisis in Emerging Europe." European Bank for Reconstruction and Development Working Paper 109 (2009). doi:10.2139/ssrn.1536645.

Berle, Adolf Augustus A, and Gardiner C Means. The Modern Corporation and Private Property. New York: McMillian, 1932.

Bertherlemy, J. C., and A. Varoudakis. "Economic Growth, Convergence Cubs, and the Role of Financial Development." Oxford Economic Papers 48, no. 2 (April 1, 1996): 300-328. doi:10.1093/oxfordjournals.oep.a028570.

Bhagwati, Jagdish. "The Capital Myth: The Difference between Trade in Widgets and Dollars." Foreign Affairs 77, no. 3 (1998): 7-12. doi:10.2307/20048871.

Bhattacharya, Sudipto, and Paul Pfleiderer. "Delegated Portfolio Management." Journal of Economic Theory 36, no. 1 (June 1985): 1-25. doi:10.1016/0022-0531(85)90076-6. 
Blackburn, Keith, and Victor T. Y. Hung. "A Theory of Growth, Financial Development and Trade." Economica 65, no. 257 (February 1998): 107-24. doi:10.1111/14680335.00116 .

Blundell, Richard, and Stephen Bond. "Initial Conditions and Moment Restrictions in Dynamic Panel Data Models." Journal of Econometrics 87, no. 1 (November 1998): 115-43. doi:10.1016/s0304-4076(98)00009-8

Boyd, John H., and Bruce D. Smith. "Intermediation and the Equilibrium Allocation of Investment Capital.” Journal of Monetary Economics 30, no. 3 (December 1992): 409-32. doi:10.1016/0304-3932(92)90004-1.

Brown, Morton B., and Alan B. Forsythe. "Robust Tests for the Equality of Variances." Journal of the American Statistical Association 69, no. 346 (June 1974): 364-67. doi:10. 1080/01621459.1974.10482955.

Buchanan, James M. The Public Principles of Public Debt: A Defense and Restatement. IL, United States: RD Irwin Homewood, 1998.

Calvo, Guillermo, and Ernesto Talvi. "Sudden Stop, Financial Factors and Economic Collapse in Latin America: Learning from Argentina and Chile." NBER Working Paper No 11153, National Bureau of Economic Research, n.d.

Checherita-Westphal, Cristina, and Philipp Rother. "The Impact of High Government Debt on Economic Growth and Its Channels: An Empirical Investigation for the Euro Area." European Central Bank Working Paper Series (1237), 2010.

Christopoulos, Dimitris K, and Efthymios G Tsionas. "Financial Development and Economic Growth: Evidence from Panel Unit Root and Cointegration Tests.” Journal of Development Economics 73, no. 1 (February 2004): 55-74. doi:10.1016/j.jdeveco. 2003.03.002.

Collins, Susan M. Comments on "Financial globalization, growth, and volatility in developing countries" by Eswar Prasad, Kenneth Rogoff, Shang-Jin Wei, and M. Ayhan Kose." in Globalization and Poverty, ed. Harrison, A. National Bureau of Economic Research Conference Report, Chicago: University of Chicago Press, 2007.

Darrat, Alif F. "Are Financial Deepening and Economic Growth Causally Related? Another Look at the Evidence." International Economic Journal 13, no. 3 (September 1999): 19-35. doi:10.1080/10168739900000002. 
De Grauwe, Paul. Economics of Monetary Union. 9th ed. Oxford: Oxford University Press, 2012.

—. "The Governance of a Fragile Eurozone." Revista de Economía Institucional 13, no. 25 (2011): 33-41. doi:10.1111/j.1467-8462.2012.00691.x.

—_ "What Kind of Governance for the Eurozone?" Revista de Economía Institucional 13, no. 25 (2011): 33-41. doi:10.2139/ssrn.1688256.

De Grauwe, Paul, and Yuemei Ji. "From Panic-Driven Austerity to Symmetric Macroeconomic Policies in the Eurozone." JCMS: Journal of Common Market Studies 51 (July 11, 2013): 31-41. doi:10.1111/jcms.12042.

Demetriades, Panicos O., and Khaled A. Hussein. "Does Financial Development Cause Economic Growth? Time-Series Evidence from 16 Countries." Journal of Development Economics 51, no. 2 (December 1996): 387-411. doi:10.1016/s0304-3878(96)00421-x.

Denizer, Cevdet A., Murat F. Iyigun, and Ann Owen. "Finance and Macroeconomic Volatility." Contributions in Macroeconomics 2, no. 1 (January 16, 2002). doi:10.2202/ 1534-6005.1048.

Devereux, Michael B., and Gregor W. Smith. "International Risk Sharing and Economic Growth." International Economic Review 35, no. 3 (August 1994): 535. doi:10.2307/ 2527072 .

Diamond, Douglas W., and Philip H. Dybvig. "Bank Runs, Deposit Insurance, and Liquidity." Journal of Political Economy 91, no. 3 (January 1983): 401-19. doi: $10.1086 / 261155$.

Diamond, Douglas W, and Raghuram G Rajan. "Banks and Liquidity." American Economic Review 91, no. 2 (May 2001): 422-25. doi:10.1257/aer.91.2.422.

Diamond, Peter A. "National Debt in a Neoclassical Growth Model." The American Economic Review 55, no. 5 (1965): 1226-50.

Diaz-Alejandro, Carlos. "Good-Bye Financial Repression, Hello Financial Crash." Journal of Development Economics 19, no. 1-2 (September 1985): 1-24. doi:10.1016/ 0304-3878(85)90036-7.

Dollar, David, and Aart Kraay. "Institutions, Trade, and Growth." Journal of Monetary Economics 50, no. 1 (January 2003): 133-62. doi:10.1016/s0304-3932(02)00206-4. 
Durham, J.Benson. "Absorptive Capacity and the Effects of Foreign Direct Investment and Equity Foreign Portfolio Investment on Economic Growth." European Economic Review 48, no. 2 (April 2004): 285-306. doi:10.1016/s0014-2921(02)00264-7.

Easterly, William, Islam Roumeen, and Joseph E Stiglitz. "Shaken and Stirred: Explaining Growth Volatility." Advances in Macroeconomic Theory, 2001, 352-72.

Edwards, Sebastian. "Openness, Productivity and Growth: What Do We Really Know?" The Economic Journal 108, no. 447 (March 1998): 383-98. doi:10.1111/14680297.00293.

Eichengreen, B. "Capital Account Liberalization: What Do Cross-Country Studies Tell Us?" The World Bank Economic Review 15, no. 3 (October 1, 2001): 341-65. doi:10.1093/wber/15.3.341.

Eichengreen, Barry, Ricardo Hausmann, and Ugo Panizza. The Pain of Original Sin. In Other People's Money. Edited by Barry Eichengreen and Ricardo Hausmann. By Barry Eichengreen and Ricardo Hausmann. United States: University of Chicago Press, 2006.

Frankel, Jeffrey A, and David Romer. "Does Trade Cause Growth?” American Economic Review 89, no. 3 (June 1999): 379-99. doi:10.1257/aer.89.3.379

Friedrich, Christian, Isabel Schnabel, and Jeromin Zettelmeyer. "Financial Integration and Growth - Why Is Emerging Europe Different?" Journal of International Economics 89, no. 2 (March 2013): 522-38. doi:10.1016/j.jinteco.2012.07.003

Fry, Maxwell J. "The Permanent Income Hypothesis in Underdeveloped Economies:" Journal of Development Economics 5, no. 4 (December 1978): 399-402. doi:10.1016/0304-3878(78)90018-4

Gibson, Heather D., Stephen G. Hall, and George S. Tavlas. "Fundamentally Wrong: Market Pricing of Sovereigns and the Greek Financial Crisis." Journal of Macroeconomics 39 (March 2014): 405-19. doi:10.1016/j.jmacro.2013.08.006

Goldsmith, Raymond W. Financial Structure and Development. New Haven: New Haven, Yale University Press, 1969.

GOURINCHAS, PIERRE-OLIVIER, and OLIVIER JEANNE. "The Elusive Gains from International Financial Integration." Review of Economic Studies 73, no. 3 (July 2006): 715-41. doi:10.1111/j.1467-937x.2006.00393.x. 
Greenwood, Jeremy, and Boyan Jovanovic. "Financial Development, Growth, and the Distribution of Income.” Journal of Political Economy 98, no. 5 (January 1990): 1076. doi: $10.1086 / 261720$

Greenwood, Jeremy, and Bruce D Smith. "Financial Markets in Development, and the Development of Financial Markets." Journal of Economic Dynamics and Control 21, no. 1 (1997): 145-81.

Grossman, Sanford J., and Oliver D. Hart. "The Costs and Benefits of Ownership: A Theory of Vertical and Lateral Integration.” Journal of Political Economy 94, no. 4 (January 1986): 691-719. doi:10.1086/261404.

Grossman, S. J., and O. D. Hart. "Disclosure Laws and Takeover Bids.” The Journal of Finance 35, no. 2 (May 1980): 323-34. doi:10.2307/2327390.

Gurley, John G, and Edward S Shaw. "Financial Aspects of Economic Development." The American Economic Review 45, no. 4 (1995): 515-38

Hansen, Lars Peter. "Large Sample Properties of Generalized Method of Moments Estimators." Econometrica 50, no. 4 (July 1982): 1029. doi:10.2307/1912775.

Harrison, Paul, Oren Sussman, and Joseph Zeira. Finance and Growth: Theory and New Evidence, 1999.

Heinemann, Friedrich, Steffen Osterloh, and Alexander Kalb. "Sovereign Risk Premia: The Link between Fiscal Rules and Stability Culture." Journal of International Money and Finance 41 (March 2014): 110-27. doi:10.1016/j.jimonfin.2013.11.002.

Hermes, Niels, and Robert Lensink. "Foreign Direct Investment, Financial Development and Economic Growth." Journal of Development Studies 40, no. 1 (October 2003): 142-63. doi:10.1080/00220380412331293707.

Hicks, John. A Theory of Economic History. United Kingdom: Oxford, Clarendon P., 1969.

Imbs, Jean. "Growth and Volatility." Journal of Monetary Economics 54, no. 7 (October 2007): 1848-62. doi:10.1016/j.jmoneco.2006.08.001.

_ . "The Real Effects of Financial Integration." Journal of International Economics 68, no. 2 (March 2006): 296-324. doi:10.1016/j.jinteco.2005.05.003.

Im, Kyung So, M.Hashem Pesaran, and Yongcheol Shin. "Testing for Unit Roots 
in Heterogeneous Panels." Journal of Econometrics 115, no. 1 (July 2003): 53-74. doi:10.1016/s0304-4076(03)00092-7.

Ireland, Patrick R. The Policy Challenge of Ethnic Diversity: Immigrant Politics in France and Switzerland. Cambridge, MA: Harvard University Press, 1994.

Jeanne, Olivier. "Why Do Emerging Economies Borrow in Foreign Currency?" IMF Working Papers 03, no. 177 (2003): 1. doi:10.5089/9781451858891.001.

Jorgenson, Dale W. Accounting for Growth in the Information Age. Handbook of Economic Growth 1, 2005.

Jorgenson, Dale W. Productivity. Cambridge, MA: MIT Press, 1995.

Kaminsky, G. L., and S. L. Schmukler. "Short-Run Pain, Long-Run Gain: Financial Liberalization and Stock Market Cycles.” Review of Finance 12, no. 2 (2008): 253-92. doi:10.1093/rof/rfn002.

Kaminsky, Graciela L, and Carmen M Reinhart. "The Twin Crises: The Causes of Banking and Balance-of-Payments Problems." American Economic Review 89, no. 3 (June 1999): 473-500. doi:10.1257/aer.89.3.473

Kindleberger, Charles Poor, and Charles P Kindleberger. "Government and International Trade." International Finance Section, no. Department of Economics, Princeton University (1978).

King, R. G., and R. Levine. "Finance and Growth: Schumpeter Might Be Right." The Quarterly Journal of Economics 108, no. 3 (August 1, 1993): 717-37. doi:10.2307/ 2118406.

Kose, Ayhan. "Volatility and comovement in an integrated world economy: An exploration," in Macroeconomic Policies in the World Economy, ed. Horst Siebert, 89122. Springer Science \& Business Media, 2004.

_ . "Financial Globalization and Economic Policies." Centre for Economic Policy Research, 2009.

Krugman, Paul. "Financing vs. Forgiving a Debt Overhang." Journal of Development Economics 29, no. 3 (November 1988): 253-68. doi:10.1016/0304-3878(88)90044-2.

Lamoreaux, Naomi. Insider Lending. Cambridge Books, 1994. 
La Porta, Rafael, Florencio Lopez-De-Silanes, Andrei Shleifer, and Robert Vishny. "Investor Protection and Corporate Valuation." The Journal of Finance 57, no. 3 (June 2002): 1147-70. doi:10.1111/1540-6261.00457.

Larrain, Borja. "Financial Development, Financial Constraints, and the Volatility of Industrial Output." Public Policy Discussion Paper 4, no. 6 (2004). doi:10.2139/ ssrn.887928.

León-González, Roberto, and Daniel Montolio. "Endogeneity and Panel Data in Growth Regressions: A Bayesian Model Averaging Approach.” Journal of Macroeconomics 46 (December 2015): 23-39. doi:10.1016/j.jmacro.2015.07.003.

Levine, Ross. "Financial Development and Economic Growth: Views and Agenda." Journal of Economic Literature 35, no. 2 (1997): 688-726.

- Handbook of Economic Growth. Edited by Philippe Aghion and Steven Durlauf. Amsterdam: North Holland, 2005.

Lucas, Robert E. Models of Business Cycles. Oxford: Blackwell Publishers, 1987.

. "On the Mechanics of Economic Development." Journal of Monetary Economics 22, no. 1 (July 1988): 3-42. doi:10.1016/0304-3932(88)90168-7.

Mankiw, Gregory N. Macroeconomics. New York, 1992.

Mankiw, N. Gregory, Edmund S. Phelps, and Paul M. Romer. "The Growth of Nations." Brookings Papers on Economic Activity 1995, no. 1 (1995): 275-310. doi:10.2307/2534576.

Manning, Alan. "The Real Thin Theory: Monopsony in Modern Labour Markets." Labour Economics 10, no. 2 (April 2003): 105-31. doi:10.1016/s0927-5371(03)000186.

McKinnon, Ronald I. Money and Capital in Economic Development. Washington: Washington, Brookings Institution, 1973.

Meade, James E. "Is the National Debt a Burden?" Oxford Economic Papers 10, no. 2 (1958): 163-83.

Merton, Robert C. and Zvi Bodie. "A conceptual framework for analyzing the financial environment" in The Global Financial System: A functional Perspective, ed. Crane D.G., et al., 3-31. Boston: Harvard Business School Press, 1995. 
Miller, Merton H. "Financial Markets and Economic Growth." Journal of Applied Corporate Finance 11, no. 3 (September 1998): 8-15. doi:10.1111/j.1745-6622.1998. tb00498.x.

Mink, Mark, and Jakob de Haan. "Contagion during the Greek Sovereign Debt Crisis." Journal of International Money and Finance 34 (2012): 102-13. doi:10.1016/ j.jimonfin.2012.11.006.

Minsky, Hyman P. "The Evolution of Financial Institutions and the Performance of the Economy." Journal of Economic Issues 20, no. 2 (June 1986): 345-53. doi:10.1080/002 13624.1986.11504505.

Missio, Sebastian, and Sebastian Watzka. "Financial Contagion and the European Debt Crisis." CESifo Working Paper: Monetary Policy and International Finance, 2011.

Modigliani, Franco. "Long-Run Implications of Alternative Fiscal Policies and the Burden of the National Debt." The Economic Journal 71, no. 284 (December 1961): 730. doi:10.2307/2228247.

Myers, Stewart C., and Nicholas S. Majluf. "Corporate Financing and Investment Decisions When Firms Have Information That Investors Do Not Have." Journal of Financial Economics 13, no. 2 (June 1984): 187-221. doi:10.1016/0304$405 \times(84) 90023-0$.

Newey, Whitney K., and Kenneth D. West. "Hypothesis Testing with Efficient Method of Moments Estimation.” International Economic Review 28, no. 3 (October 1987): 777-87. doi:10.2307/2526578.

Nguyen, Toan Quoc, Benedict J. Clements, and Rina Bhattacharya. "External Debt, Public Investment, and Growth in Low-Income Countries.” IMF Working Papers 03, no. 249 (2003): 1. doi:10.5089/9781451875904.001.

Patrick, Hugh T. "Financial Development and Economic Growth in Underdeveloped Countries." Economic Development and Cultural Change 14, no. 2 (January 1966): 174-89. doi:10.1086/450153.

Poirson, Hélène, Luca Antonio Ricci, and Catherine A. Pattillo. "External Debt and Growth.” IMF Working Papers 02, no. 69 (2002): 1. doi:10.5089/9781451849073.001.

Popov, Alexander A. "Financial Liberalization, Growth, and Risk." SSRN Electronic 
Journal, 2011. doi:10.2139/ssrn.1785671.

popov, alexander, and frank smets. "On the Tradeoff between Growth and Stability: The Role of Financial Markets." VoxEU. Org 3, 2011.

Prasad, Eswar., Raghuram. Rajan, and Arvind. Subramanian. "Foreign Capital and Economic Growth." National Bureau of Economic Research 2007, no. 1 (2007): 153230. doi:10.1353/eca.2007.0016.

Prasad, Eswar S., Kenneth Rogoff, Shang-Jin Wei, and Ayhan M. Kose. Effects of Financial Globalization on Developing Countries: Some Empirical Evidence. Washington, D.C.: International Monetary Fund (IMF), 2003.

Rajan, Raghuram G, and Luigi Zingales. "Information Reliability and a Theory of Financial Intermediation." National Bureau of Economic Research., 1996.

Ramakrishnan, Ram TS, and Anjan V Thakor. "Information Reliability and a Theory of Financial Intermediation." The Review of Economic Studies 51, no. 3 (1984): 415-32.

Reinhart, Carmen M, and Kenneth S Rogoff. "Growth in a Time of Debt." National Bureau of Economic Research, 2010.

Robinson, Joan. The Generalisation of the General Theory, and Other Essays. London: Palgrave Macmillan, 1979.

—. The Rate of Interest and Other Essays. London: McMillan, 1952.

Rodrik, Dani. "Who Needs Capital-Account Convertibility?" Essays in International Finance, 1998, 55-65.

ROUSSEAU, PETER L., and PAUL WACHTEL. "WHAT IS HAPPENING TO THE IMPACT OF FINANCIAL DEEPENING ON ECONOMIC GROWTH?" Economic Inquiry 49, no. 1 (January 2011): 276-88. doi:10.1111/j.1465-7295.2009.00197.x.

Saint-Paul, Gilles. "Fiscal Policy in an Endogenous Growth Model." The Quarterly Journal of Economics 107, no. 4 (1992): 1243-59.

Schumpeter, Joseph A. The Theory of Economic Development, 1911.

Shan, Jordan Z., Alan G. Morris, and Fiona Sun. "Financial Development and Economic Growth: An Egg-and-Chicken Problem?" Review of International Economics 9, no. 3 (August 2001): 443-54. doi:10.1111/1467-9396.00291. 
Shaw, Edward S. Financial Deepening in Economic Development. New York: Oxford University Press New York, 1973.

Sirri, Erik R, and Peter Tufano. "The Economics of Pooling." The Global Financial System: A Functional perspectiveA Functional Perspective, 1995, 81-128.

Stern, Nicholas. "The Economics of Development: A Survey." The Economic Journal 99, no. 397 (1989): 597-685.

Stiglitz, Joseph E. "Capital Market Liberalization, Economic Growth, and Instability." World Development 28, no. 6 (June 2000): 1075-86. doi:10.1016/s0305750x(00)00006-1.

- "Information and the Change in the Paradigm in Economics." American Economic Review 92, no. 3 (June 2002): 460-501. doi:10.1257/00028280260136363.

—. "On the Possibility of Informationally Efficient Markets." The American Economic Review 70, no. 3 (1980): 393-408.

Stulz, RenéM. "Managerial Control of Voting Rights." Journal of Financial Economics 20 (January 1988): 25-54. doi:10.1016/0304-405x(88)90039-6.

Wachtel, Paul. "How Much Do We Really Know about Growth and Finance?" Economic Review (Q1), 2003, 33-47.

Wei, Shang-Jin. "Connecting Two Views on Financial Globalization: Can We Make Further Progress?" Journal of the Japanese and International Economies 20, no. 4 (December 2006): 459-81. doi:10.1016/j.jjie.2006.06.003.

Williamson, Steve, and Randall Wright. "Barter and Monetary Exchange under Private Information." The American Economic Review, 1994, 104-23.

Woo, Jaejoon, and Manmohan S. Kumar. "Public Debt and Growth." IMF Working Papers 10, no. 174 (2010): 1-47. doi:10.5089/9781455201853.001. 